University of Windsor

Scholarship at UWindsor

$1-1-1969$

\title{
Synthesis and polarographic studies of beta-substituted phenylcystine derivatives.
}

\author{
Chandravadan Patel \\ University of Windsor
}

Follow this and additional works at: https://scholar.uwindsor.ca/etd

\section{Recommended Citation}

Patel, Chandravadan, "Synthesis and polarographic studies of beta-substituted phenylcystine derivatives." (1969). Electronic Theses and Dissertations. 6581.

https://scholar.uwindsor.ca/etd/6581

This online database contains the full-text of PhD dissertations and Masters' theses of University of Windsor students from 1954 forward. These documents are made available for personal study and research purposes only, in accordance with the Canadian Copyright Act and the Creative Commons license-CC BY-NC-ND (Attribution, Non-Commercial, No Derivative Works). Under this license, works must always be attributed to the copyright holder (original author), cannot be used for any commercial purposes, and may not be altered. Any other use would require the permission of the copyright holder. Students may inquire about withdrawing their dissertation and/or thesis from this database. For additional inquiries, please contact the repository administrator via email (scholarship@uwindsor.ca) or by telephone at 519-253-3000ext. 3208. 
SYNTHESIS AND POLAROGRAPHIC STUDIES

OF BETA-SUBSTITUTED PHENYLCYSTINE DERIVATIVES

BY

CHANDRAVADAN PATEL

\section{A Thesis}

Submitted to the Faculty of Graduate studies through the Department of Chemistry in Partial Fulfillment of the Requirements for the Degree of Master of Science at the University of Windsor

Windsor, Ontario

1969 
UMI Number: EC52764

\section{INFORMATION TO USERS}

The quality of this reproduction is dependent upon the quality of the copy submitted. Broken or indistinct print, colored or poor quality illustrations and photographs, print bleed-through, substandard margins, and improper alignment can adversely affect reproduction.

In the unlikely event that the author did not send a complete manuscript and there are missing pages, these will be noted. Also, if unauthorized copyright material had to be removed, a note will indicate the deletion.

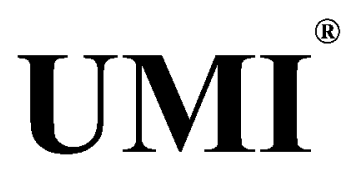

\section{UMI Microform EC52764}

Copyright 2008 by ProQuest LLC.

All rights reserved. This microform edition is protected against unauthorized copying under Title 17, United States Code.

ProQuest LLC

789 E. Eisenhower Parkway

PO Box 1346

Ann Arbor, MI 48106-1346 
AET 5408

Approved by :

Roger 1. Pilot

Mequareat

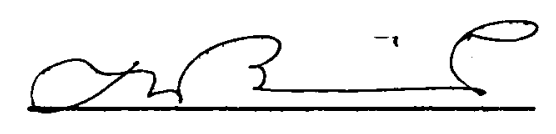

270722

Reproduced with permission of the copyright owner. Further reproduction prohibited without permission. 


\begin{abstract}
N-benzoyl-threo- $-\underline{B}-$-substituted cystine ethyl esters have been prepared. These phenyl-, p-chlorophenyl-; pmethoxyphenyl-, and $\underline{p}$-nitrophenylcystine ethyl esters were prepared from the corresponding cysteine derivatives by oxidation. The substituted cysteine derivatives were synthesized from the corresponding N-benzoyl-s-dichlorothreo- $\underline{\beta}-\underline{p}$-substituted phenylcysteine ethyl esters which were synthesized via the condensation of dichlorothioacetic acid and the corresponding ethyl cinnamates. Substituted cinnamates were prepared from the corresponding azlactones which in turn were synthesized from parasubstituted benzaldehydes and hippuric acid.

A polarographic method was developed for the determination of $\mathrm{N}$-benzoy 1 -threo- $\underline{\beta}-\underline{p}$-substituted cysine ethyl esters. An attempt was made to find a correlation between the halfwave potential and the substituent constant (Taft constant $\left.\underline{\sigma}^{*}\right)$

Ultraviolet spectra were measured for the $\underline{\alpha}$-substituted cystines and the $\mathrm{N}$-benzoyl-threo- $\underline{\beta}-\underline{p}$-substituted cystine ethyl esters in appropriate solvents. A correlation between the wave length and half-wave potential was investigated.
\end{abstract}




\section{ACKNOWLEDGEMENTS}

The author wishes to acknowledge with deep gratitude the direction of Dr. R. J. Thibert without whose patience and guidance this work could not have been completed.

I would also wish to acknowledge the support of the National Research Council of Canada who sponsored this study in part. Finally, thanks to Mr. R. J. Walton for his assistance in the polarographic studies. 
TABLE OF CONTENTS

Page

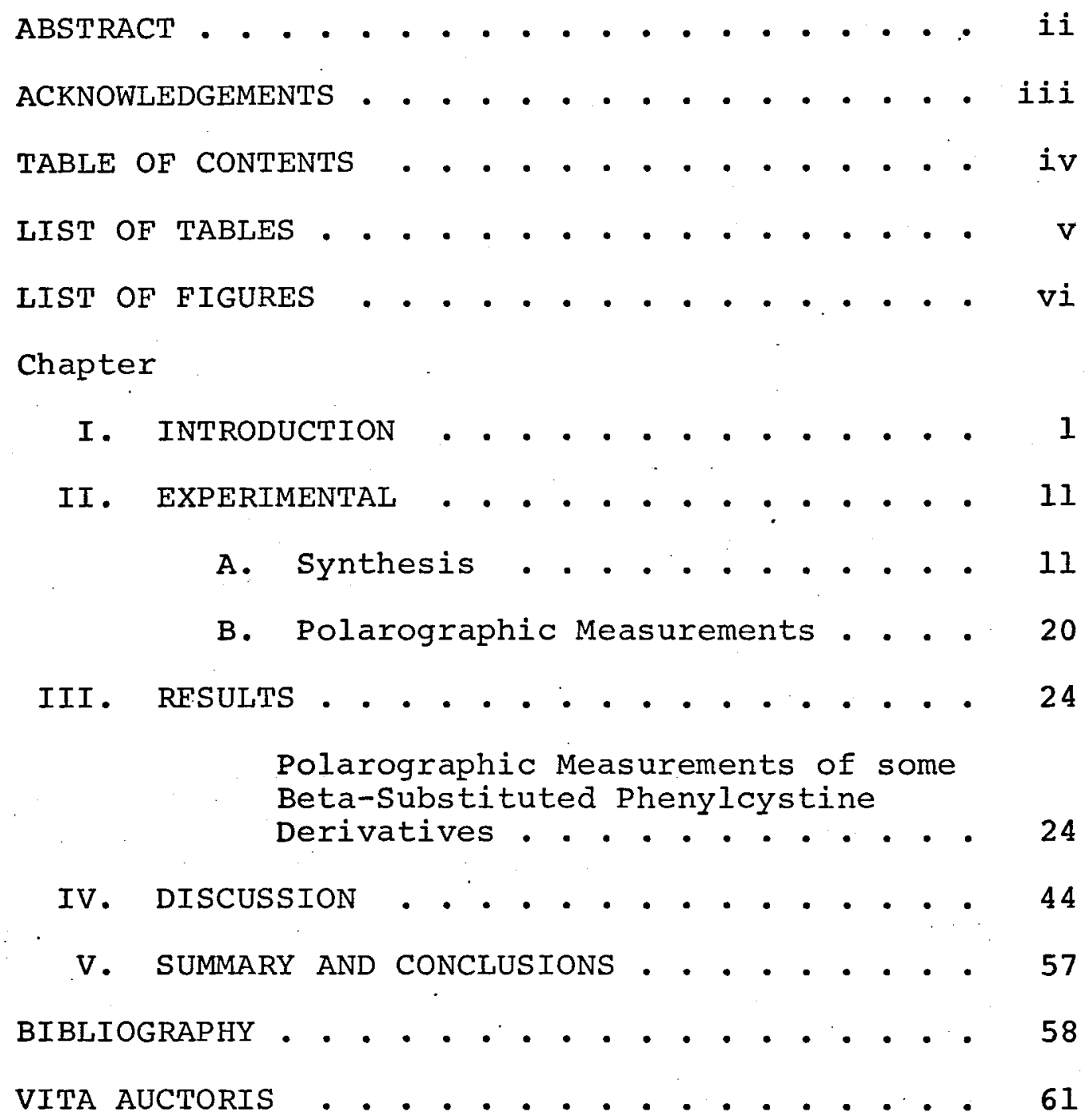




\section{LIST OF TABLES}

Table

Page

I. Enzymatic Versus Polarographic Reduction of the Alpha-Substituted Cystines . . . 3

II. Properties of Some Amino Aciōs and $\sigma^{*}$ values ................. 4

III. Resonance Effects of Groups . . . . . . 4

IV. Effect of Concentration on Diffusion Current . . . . . . . . . . . 25

V. Diffusion Coefficient . . . . . . . 33

VI. Slope of E Vs. $\log \left(i_{d^{-i}}\right) / i^{2}$ Plot. . . 37

VII. Values of $E$ and $\log \left(i_{\mathrm{d}}-\mathrm{i}\right) / \mathrm{i}^{2} \cdot . \cdot . \cdot 38$

VIII. Half-Wave Potential . . . . . . 40

IX. Absorption Characteristics of Some Amino Acids and Derivatives . . . . . . . . 43

X. Equilibrium Constants of p-Substituted Phenyl Acetate and p-Substituted Cinnamates ............ 52

XI. Half-Wave Potentials and $\underline{\sigma}_{I} ; \underline{\sigma}^{*} \cdot . \cdot . \cdot 56$ 
LIST OF FIGURES

Figure

Page

1. Synthesis of Beta-Substituted Phenylcystine • . 12

2. The cell . . . . . . . . . . . . . 21

3. Effect of Concentration on Diffusion Current . . 27

4. Typical Polarogram . . . . . . . . . . . 29

5. Plot of $\log \left(i_{\mathrm{d}^{-i}}\right) / \mathrm{i}^{2}$ vs. $\mathrm{E} \cdot$. . . . . . 36

6. Plot of $\log \left(i \mathrm{~d}^{-i}\right) / \mathrm{i}$ vs. E . . . . . . . 42

7. Synthesis of Beta Phenylcystines . . . . . . 45

8. Synthesis of Beta Phenylcystines . . . . . . 46

9. Plot of $\log \mathrm{k}$ vs. $\log$ of for Ethyl
p-Substituted Phenyl Acetate. . . . . . . 53

10. Plot of $E_{\frac{1}{2}}$ vs. $\sigma^{*}$ and $\sigma_{I} \cdot$. . . . . . . 55

vi 
CHAPTER I

INTRODUCTION

Polarographic studies have been carried out (1) in this laboratory on alpha-substituted cystines in aqueous media. Enzymatic reduction rates of cystine and alphasubstituted cystines have also been studied (2). Cystine reductase (EC 1.6.4.1) has been utilized in these studies.

The overall enzymatic reduction could be illustrated as :

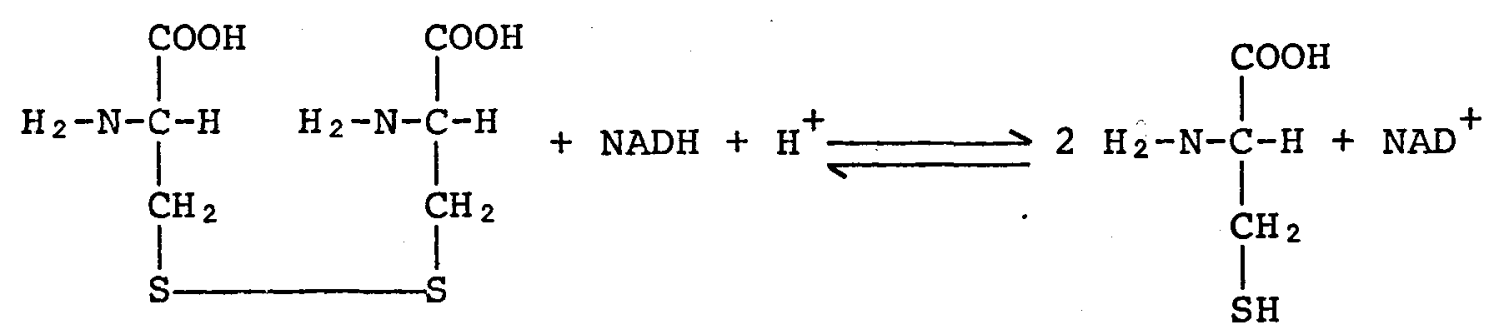

In the literature, it has been reported that the lack of alpha-hydrogen atom tends to make the amino acid inert in many enzymatic reactions. In the case of alphasubstituted cystines as shown in Table I, the alpha-hydrogen atom is not necessary for this enzymatic reduction. However, there is no pronounced correlation between the structure and the ease of reduction of these alpha-substituted cystines.

Table II illustrates the polarographic half-wave potential and the $\mathrm{pH}$ values at the first and second inflection points of these alpha-substituted cystines as determined by Thibert (1). Taft values $\left(\underline{\sigma}^{*}\right)$ have been added to the original table to establish whether one can 


\section{TABIE I}

ENZYMATIC VERSUS POLAROGRAPHIC REDUCTION OF THE ALPHASUBSTITUTED CYSTINES

\section{Iegend}

Initial velocities and first order rate constants determined using $1 \times 10^{-3} \mathrm{M}$ L-cystine, DL-cystine, $\underline{\alpha}$-substituted cystine in $0.025 \mathrm{M}$ phosphate buffer (pH 6.2). First order rate constants were calculated from the first order rate equation. 
TABLE I

ENZYMATIC VERSUS POLAROGRAPHIC REDUCTION OF THE ALPHASUBSTITUTED CYSTINES*

\begin{tabular}{lccc}
\hline Amino Acid & $\begin{array}{c}\mathrm{v}_{\circ} \\
\left(\mu \mathrm{Min}{ }^{-1}\right)\end{array}$ & $\begin{array}{c}\mathrm{k} \\
\left(\mathrm{min}^{-1}\right)\end{array}$ & $\begin{array}{c}\text { Half-Wave } \\
\text { Potential (volt) }\end{array}$ \\
\hline L-Cystine & 0.415 & 415 & -0.536 \\
$\underline{\alpha-M}$-thyl & 0.350 & 350 & -0.514 \\
DL-Cystine & 0.346 & 346 & ---- \\
$\underline{\alpha-n-P r o p y l}$ & 0.345 & 345 & -0.186 \\
$\underline{\alpha-n-B u t y l}$ & 0.318 & 318 & -0.202 \\
$\underline{\alpha-P h e n y l}$ & 0.264 & 264 & -0.184 \\
$\underline{\alpha-E t h y l}$ & 0.190 & 190 & -0.249 \\
$\underline{\alpha-I s o p r o p y l}$ & 0.167 & 167 & -0.370 \\
\hline
\end{tabular}

* As shown in reference (2) 
TABLE II

PROPERTIES OF SOME AMINO ACIDS AND $\Omega^{*}$ VALUES*

\begin{tabular}{|c|c|c|c|c|}
\hline $\begin{array}{l}\text { Amino Acid } \\
\text { Cystine }\end{array}$ & $\begin{array}{l}\text { Half-Wave } \\
\text { Potential } \\
\text { (V) }\end{array}$ & $\begin{array}{l}\text { pH at first } \\
\text { Inflection } \\
\quad \text { point }\end{array}$ & $\begin{array}{l}\mathrm{pH} \text { at second } \\
\text { Inflection } \\
\quad \text { point }\end{array}$ & $\underline{\sigma}^{*}$ \\
\hline L-Cystine & -0.536 & 10.25 & 8.68 & +.49 \\
\hline$\alpha-$ Methy 1-DI- & -0.514 & 10.44 & 9.08 & 0.00 \\
\hline$\underline{\alpha-E t h y} 1-\mathrm{DL}-$ & -0.249 & 10.33 & 8.62 & -.10 \\
\hline$\underline{\alpha}-n-\operatorname{propy} I-\mathrm{DL}-$ & -0.186 & 10.32 & 8.63 & -.11 \\
\hline$\underline{\alpha}-\mathrm{n}$-Isopropy $1-\mathrm{DL}-$ & -0.370 & 10.38 & 8.67 & -.19 \\
\hline$\underline{\alpha}-\mathrm{n}-\mathrm{Buty} 1-\mathrm{DL}-$ & -0.202 & 10.48 & 8.78 & -.13 \\
\hline$\underline{\alpha-P h e n y} I-D L-$ & -0.184 & 9.49 & 8.19 & +.60 \\
\hline
\end{tabular}

* These values were obtained from reference

(1)

TABLE III

RESONANCE EFFECTS OF GROUPS*

\begin{tabular}{|c|c|c|c|}
\hline $\begin{array}{l}\text { Substituent } \\
\text { Group }\end{array}$ & $\begin{array}{l}\text { Inductive } \\
\text { Effect }\end{array}$ & $\begin{array}{l}\text { Resonance } \\
\text { Effect }\end{array}$ & $\begin{array}{c}\text { Shift of } \\
\text { E } \frac{1}{2} \text { Towards }\end{array}$ \\
\hline $\mathrm{H}$ & - & - & - \\
\hline $\mathrm{OCH}_{3}$ & $-I$ & $+\mathrm{R}$ & positive \\
\hline Cl & $-I$ & $+\mathrm{R}$ & intermediate \\
\hline $\mathrm{NO}_{2}$ & $-I$ & $-R$ & negative \\
\hline
\end{tabular}

* These values were obtained from reference (3) 
find any linear correlation between the structure and the half-wave potential. The $\underline{\sigma}^{*}$ values are dependent on the kind of substituent but are independent of the nature of the reactive group $\left(-S^{-}-S_{-}\right)$, the type of reaction, and the reaction condition. These values do not take into account the mesomeric interaction between the reactive group and the substituent (which in this case is separated by two methylene groups). It indicates the direct polar interaction between the substituent and the polarographically... active group $(-\mathrm{S}-\mathrm{S}-)$.

Since no linear correlation could be established between the half-wave potential and the $\sigma^{*} v a l u e s$, one can predict that there is no polar effect due to the substituents in the alpha-position of alpha-substituted cystines. It is possible that there might be a steric interaction instead of the polar interaction. Therefore, one should use the following relationship (4):

$$
E_{\frac{1}{2}}=P+M_{\pi}+S
$$

Where $\mathrm{P}=$ change in the polar activation energy increment $M_{\pi}=$ change in the mesomeric energy increment $\mathbf{s}=$ change in the total steric energy increment $P, s$ and $M_{\pi}$ are often independent variables.

In order to understand and differentiate between all these effects, a proper choíce of selection rules for a given series of reactions have to be established. Since 
steric effects are non-additive, it seems probable that no general relationship or simple correlation between the steric effect and the substituent may be found in this series compared to some other series reported in the literature (4). The unavailability of the special substituent constants makes it difficult to choose the proper kind of values. Sometimes it is possible to make an estimate based on the number of atoms between the atom carrying the substituent and that carrying the electroactive group. Normally one has to depend on a trial-anderror approach. In case of alpha-substituted cystines, both polar and steric<smiles>[R]C(N)(CSSCC([R])(N)C(=O)O)C(=O)O</smiles>

effects might be of importance since the effective carboxylic and amino group had not been taken into consideration. In such a case one could make use of the following relationship :

$$
E_{\frac{1}{2}}=\frac{\sigma^{*} \text { carboxylic }+\sigma^{*} \text { amino }+\sigma^{*}}{3}
$$

Similar calculations have been cited (4) where the correlation was carried out by the use of $\left(\sigma_{m}+\sigma_{-p}^{\sigma}\right) / 2$ values. In order to understand the effect of substituents and their relationship to the reduction of cystine polarographically, it was thought feasible to move the substituents 
from the alpha position to the beta position. In this way, a pronounced polar effect if any, could be established at the carbon atom next to the electroactive group.<smiles>[X]C(SC)C([Z])C(=O)O</smiles><smiles>[R]C(=O)N[C@H](C(=O)OCC)[C@H](NC([R])=O)[C@H]([Z])SC</smiles>

Furthermore in order to understand the true polar effect on the reduction of beta-p-substituted phenylcystine polarographically, the free carboxylic- and the aminogroups were blocked in order to minimize any effects produced by hydrogen bonding, (since it is known that hydrogen bonding tends to shift $E_{\frac{1}{2}}$ towards a more positive potential). In order to differentiate between the various contributions by the substituents, a proper selection of the substituents had to be made according to the following rules:

1) It should have practically negligible steric and mesomeric effect on the reactive group.

2) The substituent effects should only be polar, so that the following condition could be fulfilled.

$$
E_{\frac{1}{2}}=P \text { where } P=\text { polar effect }
$$

The effect of a substituent is expressed relative to that of hydrogen. An electrophilic group is more negative 
than hydrogen [-I (inductive) and $-\mathrm{R}$ (resonance)] while a nucleophilic group is more positive ( $I$ and $+R)$. Keeping these rules in mind, the following substituents were chosen for the synthesis of $\mathrm{N}$-benzoyl-threo- $\underline{\beta}-\underline{p}-$ substituted phenylcystine ethyl esters which were oxidized to the cystine derivatives by iodine in dioxane. Table III shows the groups and their inductive and resonance effects, as well as the type of shift one can predict for the half-wave potentials. The substitution of the group was in the para position on the benzene ring, since in the absence of other effects, the reduction of benzene derivatives with a reducible group in the side chain and $a-R$ substituent effect, the reduction occurs at a more positive potential than at any other position of the substituent (ortho, meta). In cases where the p-substituted benzene is attached directly to the electro-active group (-S-S) as in various alkyl and diphenyl disulphides $(5,6)$ as reported by Hall, Karchmer, and Walker, the effect of the substituents is found to be very pronounced and a linear correlation between half-wave potential and Taft's value has been established. In these cases it has proved useful to use $\sigma^{-}$values which were determined from the reactions of para-substituted phenols and anilines (7-9). One can then use the following equation (4):

$$
E_{\frac{1}{2}}=\rho \pi, R \underline{\sigma}^{-}
$$


where $\frac{\rho \pi}{i}=$ reaction constant expressed in volts (expresses the susceptibility of the reduction process to the polar effects of substituents).

For reaction series of the type $X-Y-R$, where the reactive group $R$ undergoes electro-reduction under certain conditions and $\mathrm{x}$ is the substituent which is not directly involved in the reaction, Zuman (4) has demonstrated that in such series of compounds, polar, mesomeric and steric effects can often be differentiated, and that an accurate comparison of polarographic half-wave potentials is possible.

Brdicka, Roncato, Kolthoff and Barnum (10-13)have studied cystine polarographically in aqueous media. They have established that the half-wave potential in this media is $\mathrm{pH}$ dependent and have shown the quantitative relationship between diffusion current (wave-height) and the concentration of the cystine. The rate-determining step of the electrochemical reduction is believed to be the cleavage of the $(-S-S-)$ bond in a two-electron step as shown here:

$$
\mathrm{RSSR}+2 \overline{\mathrm{e}}+2 \mathrm{H}^{+} \longrightarrow 2 \mathrm{RSH}
$$

The equation of the polarographic wave then is given as follows (14): 


$$
E_{D . M . E}=E^{1}+0.0295 \log \left(i_{d}-i\right) / i^{2}
$$

where $E^{1}=E^{\circ}-0.0591 \mathrm{pH}$ and predicts that a plot of $E_{D . M . E}$ vs $\log i_{d^{-i / i}}{ }^{2}$ should be linear with a slope of $29.5 \mathrm{mV}$. Furthermore, the above equation predicts that $\mathrm{E}_{\frac{1}{2}}=\mathrm{E}^{1}-0.0295 \log ^{i_{\mathrm{d} / 2}}$

Investigation of the p-substituted cystine derivatives and their electrochemical behaviour has been carried out using conventional polarography in non-aqueous media.

other studies including oxidation-reduction reactions of cysteine-cystine as well as chelate formation with copper salts have been reported in literature (15). Chelates of cysteine have been used to afford some protection against the effect of ionizing radiation on the animal (rat) $\operatorname{cell}(16,17)$. All these substituted cysteines and cystines ( $\underline{\alpha}$ and $\underline{\beta}$ ) could be further investigated along this line. Thibert and co-workers used N-bromosuccinimide in the simultaneous determination of cysteine-cystine in enzymatic reactions. This quantitative method which uses Bordeaux Red as an indicator could be used to determine the betasubstituted cysteines and cystines $(18,19)$.

The relation between the half-wave potentials and the absorption spectra of polycyclic aromatic hydrocarbons has been studied by Bergman (20). An attempt was made in our studies to correlate the half-wave potentials of the $\underline{\beta}$-phenylcystine derivatives with the absorption band at $\lambda_{\max } 204$ which is characteristic of disulphide absorption (21). 


\section{A. The Synthesis of Beta-Substituted Phenylcystine Derivatives}

The following substituted amino acid derivatives were synthesized: N-benzoyl-threo- - -phenylcystine ethyl ester, N-benzoyl-threo- $\underline{\beta}-\underline{p}$-methoxyphenylcystine ethyl ester, N-benzoyl-threo- $-\underline{-}-\mathrm{p}-\mathrm{chlorophenylcystine} \mathrm{ethyl}$

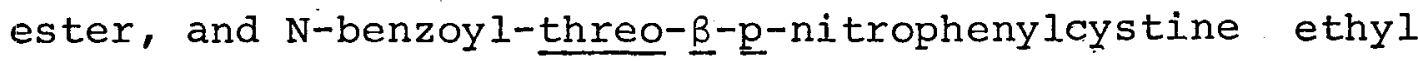
ester. The syntheses and configuration of the $\underline{\beta}$-phenylcysteineshave been previously reported $(23,24)$. As one of the typical examples of the series, Figure II shows in detail the synthesis of $\mathrm{N}$-benzoyl-threo- - -phenylcystine ethyl ester. Most of the intermediates and all of the four final products were synthesized for the first time in this laboratory.

Elemental analyses were carried out by the Schwarzkopf Microanalytical Laboratory, 56-19 37th Avenue, Woodside 77, New York. Infrared spectra were run on each intermediate and the final compound and the specific bands identified in our laboratories. Melting points reported here are uncorrected. A Fisher-Jones melting point apparatus and a Beckman IR-10 spectrophotometer were used in these studies. 


\section{FIGURE $\quad 1$}

SYNTHESIS OF BETA-SUBSTITUTED PHENYLCYSTINE DERIVATIVES

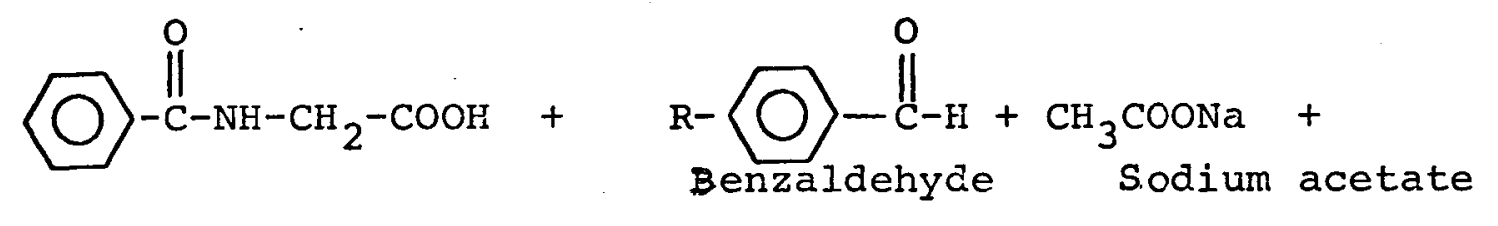

$$
\begin{aligned}
& \mathrm{R}=\mathrm{CH}_{3} \mathrm{O}- \\
& \mathrm{NO}_{2}- \\
& \text { cl - } \\
& 100^{\circ} \mathrm{C}
\end{aligned}
$$

$\left(\mathrm{CH}_{3} \mathrm{CO}\right)_{2} \mathrm{O}$ Acetic anhydride

Ethy $1-\mathrm{N}-$ benzoyl-p- substituted cinnamate

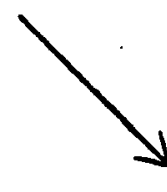

$\mathrm{Cl}_{2} \mathrm{CH}-\mathrm{C}^{\prime O}$

Dichloroacetic acid

$\mathrm{C}_{6} \mathrm{H}_{5} \mathrm{COCl} \quad \begin{aligned} & \text { Benzoyl } \\ & \text { chloride }\end{aligned}$

reflux<smiles>CC(Cl)C(=O)Cl</smiles>

1) $\mathrm{H}_{2} \mathrm{~S}$ gas

(2) $0^{\circ} \mathrm{C}$

Dichlorothioacetic acid

$100^{\circ} \mathrm{C}$

5 hrs. 
<smiles>[Z15]COC(=O)C(NC(=O)c1ccccc1)C(SC(=O)C([CH])[CH2])c1ccc([R])cc1</smiles>

N-Benzoy1-s-dichlorothreo-B-p-substituted phenylcysteine ethyl ester

$$
\text { Al- }\left(\mathrm{OC}_{3} \mathrm{H}_{7}\right)_{3}
$$
Ethanol

$100^{\circ} \mathrm{C}$<smiles>[R]COC(=O)C(NC(=O)c1ccccc1)C(S)c1ccc([R])cc1</smiles>

N-Benzoy 1-threo-

$\underline{\beta}$-p-substituted phenylcysteine ethyl ester

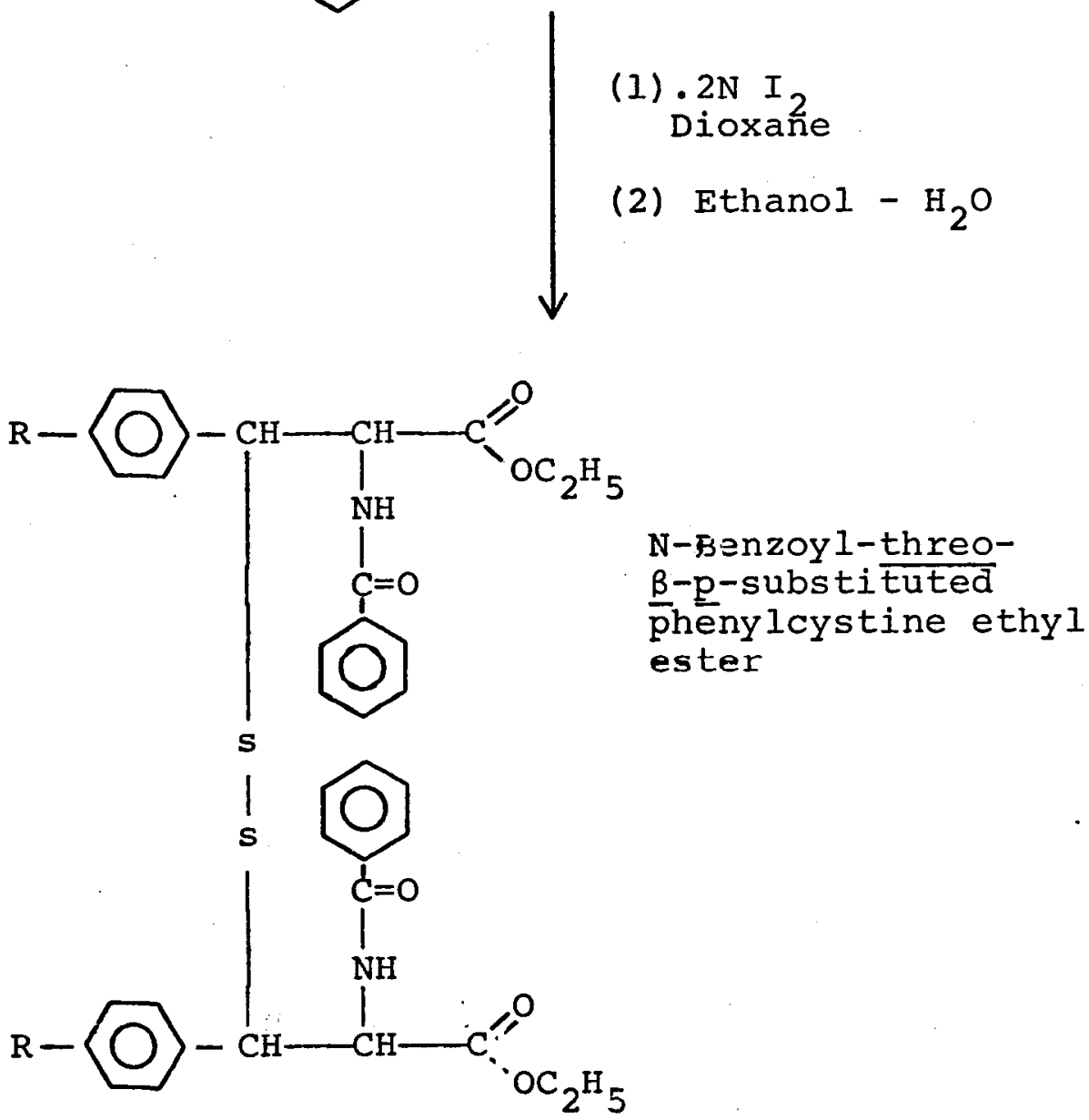




\section{Azlactone (oxazolones)}

The procedure of Erlenmeyer et al. (25-29) was employed to prepare these substituted azlactones. In the synthesis of 2-phenyl-4-benzylidene oxazolone, hippuric acid (54.2 g; 0.33 mole); sodium acetate anhydrous (24.6 g; 0.33 mole); benzaldehyde (31.8 ml; 0.33 mole) and acetic anhydride ( $85.1 \mathrm{ml} ; 0.83$ mole) were shaken at intervals of 2 minutes for the first fifteen minutes on a steam bath until a clear yellow liquid was obtained. The mixture was further heated for one hour during which time a solid product was obtained. The mixture was cooled, filtered with suction, washed with alcohol to remove excess benzaldehyde and recrystallized from benzene. The melting point of the product (pale yellow needles) was $164-166^{\circ} \mathrm{C}$ (yield $75 \%$ ). The reported $\mathrm{mp}$ is $165-166^{\circ} \mathrm{C}$.

In a similar manner the following substituted oxazolones, 4-p-nitrobenzylidene- (mp $235-237^{\circ} \mathrm{C}$ dec; yield 67\%)., 4-p-methoxybenzylidene- (mp $155-156^{\circ} \mathrm{C}$; 1 it. mp $156.5^{\circ} \mathrm{C}$; yield 42\%), 4-p-chlorobenzylidene- (mp 195-196 ${ }^{\circ} \mathrm{C}$, yield 55\%) and 4-p-isopropylbenzylidene- (mp 119-121 ${ }^{\circ} \mathrm{C}$; lit. mp $121^{\circ} \mathrm{C}$; yield 34\%) were prepared using p-nitrobenzaldehyde, anisaldehyde, p-chlorobenzaldehyde and p-isopropylbenzaldehyde, respectively. Infrared spectra of the compounds in $\mathrm{KBr}$ pellets were recorded. 
Ethyl-N-benzoyl-p-substituted cinnamate

A route previously found by Erlenmeyer et al. (25-29) was utilized in the preparation of these esters. The preparation of ethyl-a-benzamidocinnamate will illustrate a typical example of these syntheses.

A suspension of 2-phenyl-4-benzylidene oxazolone (12 $\mathrm{g} ; 0.05$ mole) was refluxed with a mixture of absolute ethanol (75 ml; 2.1 mole) and concentrated sulphuric acid (5 ml) for 3-4 hours until a clear solution was obtained. Excess ethanol was evaporated on a water-bath and the white residue was washed with water until the filtrate was free from any traces of sulphuric acid. The crude product was recrystallized from ethanol. The mp was 148$149^{\circ} \mathrm{C}$; (yield $85 \%$ ). The reported value is $149^{\circ} \mathrm{C}$. Using the above procedure the following compounds: ethyl-a-benzamido-p-methoxycinnamate (mp $146-147^{\circ} \mathrm{C}$; yield 91.6\%); ethyl- $\alpha$-benzamido-p-chlorocinnamate (mp $149-150^{\circ} \mathrm{C}$; yield 73.3\%); ethyl- $\alpha$-benzamido-p-nitrocinnamate (mp 165$166^{\circ} \mathrm{C}$; yield $80 \%$; lit. mp $\left.165-166^{\circ} \mathrm{C}\right)$; and ethyl-a-benzamidop-isopropylcinnamate (mp $161-163^{\circ} \mathrm{C}$; yield $92 \%$; 1it. mp $164^{\circ} \mathrm{C}$ ) were prepared. Infrared spectra were run on each of these compounds using $\mathrm{KBr}$ pellets. N-Benzoyl-S-dichloroacetyl-threo- $\beta$-p-substituted phenylcysteine ethyl esters

The method of Sicher et al. $(23,24)$ was used for the 
synthesis of these series of compounds. The preparation of $\mathrm{N}$-benzoyl-S-dichloroacetyl-threo- $\underline{B}-\underline{p}$-phenylcysteine ethyl ester will serve as a typical example of these series.

A mixture of ethyl- $\underline{\alpha-b e n z a m i d o c i n r a m a t e ~} 16.8 \mathrm{~g}$; 0.023 mole) and dichlorothioacetic acid (10 ml) was refluxed on a steam bath for 5 hours until a viscous reddish syrup was obtained. After cooling and addition of ether, scratching immediately induced the separation of white crystals, which after crystallization from ethanol gave a mp $128-131^{\circ} \mathrm{C}$ (yield $40 \%$; 1it. mp $128-131^{\circ} \mathrm{C}$ ).

In the same manner the following analogous $\mathrm{p}$-methoxy(mp $108-109^{\circ} \mathrm{C}$; yield $31 \%$ ); p-chloro- (mp 133-134 ${ }^{\circ} \mathrm{C}$; yield 30.9\%); p-isopropyl- (mp $146^{\circ} \mathrm{C}$; yield 0.6\%) and p-nitro(mp $142-143^{\circ} \mathrm{C}$; yield $38 \%$; lit. mp $142^{\circ} \mathrm{C}$ ) esters were prepared. In the case of the p-isopropyl-derivative, crystallization took as long as a week. A good yield of p-isopropyl adduct was not obtained and, therefore, no further work was done on this compound. In the case of p-nitro adduct, it was necessary to remove the excess dichlorothioacetic acid prior to the addition of ether.

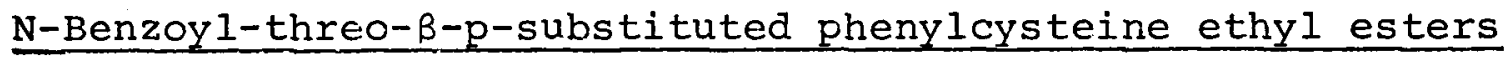
The reduction of the $\mathrm{N}$-benzoyl-S-dichloroacetyl-threoB-p-substituted phenylcysteine ethyl esters was accomplished using the Meerwein-Ponndorf-Verley method (30). 
N-Benzoyl-S-dichloroacetyl-threo- - -phenylcysteine ethyl ester $(2.2 \mathrm{~g} ; 0.005 \mathrm{~mole})$ and powdered aluminium isopropoxide ( $1 \mathrm{~g} ; 0.005 \mathrm{~mole}$ ) in ethanol $(50 \mathrm{ml}$ ) were refluxed for four hours in a 100-ml, round-bottomed flask equipped with a condenser. Excess ethanol was evaporated and the dry residue was treated with $15 \%$ tartaric acid solution $(100 \mathrm{ml})$. The mixture was filtered and the residue dissolved in ether. On evaporation of ether, a white solid was obtainea which was crystallized from isopropanol (mp $125-126^{\circ} \mathrm{C}$; yield $70 \%$; lit. mp $125-126^{\circ} \mathrm{C}$ ) .

Similarly, p-methoxy-, p-chloro-, and p-nitrophenylcysteine ethyl esters were prepared. In the case of the p-nitrocompound, a residue was formed during the refluxing period, which was filtered before evaporation. The yield, analysis and the $m p$ of the white resialue for the $N$-benzoyl- $\underline{B}-\underline{p}-$ substituted phenylcystine ethyl esters were as follows: p-methoxy- (yiela $41.6 \% ; \mathrm{mp} 139-140^{\circ} \mathrm{C}$ )

Anal. calcd. for $\mathrm{C}_{18}{ }_{19} \mathrm{O}_{3} \mathrm{NS}: \mathrm{C}, 62.42 ; \mathrm{H}, 6.04 ; \mathrm{N}, 4.66$ $S, 9.40$.

Found: $\mathrm{C}, 62.49 ; \mathrm{H}, 6.02 ; \mathrm{N}, 4.02 ; \mathrm{S}, 9.17$.

E-chloro- (yield $37 \%$; mp $147-148^{\circ} \mathrm{C}$ )

Anal. calcd. for $\mathrm{C}_{18} \mathrm{H}_{18}{ }^{0}{ }^{\mathrm{NSCl}}: \mathrm{C}, 59.16 ; \mathrm{H}, 5.25 ; \mathrm{N}, 4.04$; $\mathrm{S}, 8.87 ; \mathrm{Cl}, 9.78$.

Found: $\mathrm{C}, 59.40 ; \mathrm{H}, 4.95, \mathrm{~N}, 3.85 ; \mathrm{S}, 8.81 ; \mathrm{Cl} 9.78$. 
p-nitro- (yield 75\%; mp $134-135^{\circ} \mathrm{C}$ )

Found: $C, 50.38 ; \mathrm{H}, 4.94$. These analysis (of $\mathrm{C}$ and $\mathrm{H}$ ) correspond to $\underline{B}-\underline{p}$-nitrophenylcysteine ethyl ester.

Anal. calc. for $\mathrm{C}_{11} \mathrm{H}_{14} \mathrm{O}_{4} \mathrm{~N}_{2} \mathrm{~S}: \mathrm{C}, 48.88$; $\mathrm{H}, 5.18$.

Dichloroacetyl chloride

The method employed by Brown (31) for the preparation of chloroacetyl chloride was used. Yield obtained was about $65 \%$ with a boiling point of $107^{\circ} \mathrm{C}$, which agrees well with the literature boiling point $107-108^{\circ} \mathrm{C}$. Dichlorothioacetic acid

The conversion of dichloroacetyl chloride to dichlorothioacetic acid has been reported by Cunneen (32). A rapid stream of dry hydrogen sulphide gas was passed through a well-cooled $\left(0^{\circ} \mathrm{C}\right)$ solution of dichloroacetyl chloride (500 g; 3.76 mole) and powdered dry aluminium chloride (10 g) until the evolution of hydrogen chloride ceased (8-10 hrs). Distillation of the reaction mixture yielded dichlorothioacetic acid as a pale green liquid (bp $56^{\circ} \mathrm{C} / 16 \mathrm{~mm}$; yield $60.9 \%$; lit. bp $\left.56^{\circ} \mathrm{C} / 16 \mathrm{~mm}\right)$. N-benzoyl- $\beta-$ p-substituted phenylcystine ethyl esters The oxidation of cysteine derivatives to disulphides was accomplished by use of $0.2 \mathrm{~N}$ iodine solution in dioxane. The excess iodine was then removed by treatment with ethanolwater. The following synthesis of $\mathrm{N}$-benzoyl-threo- $\underline{\beta}-\underline{p}-$ phenylcystine ethyl ester will serre to illustrate a typical case. A cysteine derivative $(250 \mathrm{rg})$ was dissolved in $40 \mathrm{ml}$ 
of dioxane. This clear solution was titrated with $0.2 \mathrm{~N}$ iodine solution until an excess of iodine was indicated by starch paper. The solution was evaporated to dryness and the residue treated with 5-10 $\mathrm{ml}$ of an ethanolwater mixture. The white precipitate formed was filtered and washed with a small amount of ethanol and recrystallized with ethanol. or ethanol-water. The yield was nearly quantitative, although a considerable loss resulted from washing and recrystallization. (Yield $150 \mathrm{mg}$; $\mathrm{mp} 135^{\circ}-$ $\left.138^{\circ} \mathrm{C}\right)$. No attempt was made to recover the lost product from the solvent. Infrared spectra indicated the disappearance of the SH band.

The above method was used in the synthesis of the p-methoxy- (mp $\left.153-155^{\circ} \mathrm{C}\right)$; p-chloro- (mp 198-200 $\left.{ }^{\circ} \mathrm{C}\right)$; and p-nitro- (mp $230-232^{\circ} \mathrm{C}$ ) derivatives. The yields obtained ranged from $40-75 \%$. 
B. Polarographic Measurements of Beta-Substituted Phenylcystine Derivatives

Materials and Methods

The Sargent (Sargent-Welch Scientific Company, 7300 North Linder Avenue, Skokie, Illinois) Model XVI Polarograph and Model A I.R. compensator were used for this study. It was found necessary to develop and make use of a special H-type cell as illustrated in Figure 2, for the non-aqueous polarographic studies (33). The need for a reference electrode that would not involve too much contact of water with anhydrous methanol, led us to make a calomel electrode in methanol. A paste of calomel and mercury was placed on a mercury pooi and covered with methanol previously saturated with potassium chloride at room temperature $\left(25^{\circ} \mathrm{C}\right)$. The system was allowed to reach equilibrium by letting it stand for a couple of days. This cell was measured against an aqueous S.C.E. Both reference electrodes were closed with ground glass joints to prevent evaporation. The resistance of the droppingmercury electrode(D.M.E. With respect to the saturated calomel reference electrode (S.C.E) $(2500 \Omega)$ and (D.M.E.) with respect to the methanol-saturated calomel electrode (M.S.C.E) $(5700 \Omega)$ was measured using a conductivity bridge. Both reference cells were connected to D.M.E. by a side arm containing an agar plug saturated with $\mathrm{KCl}$. All 
FIGURE 2

THE CELL
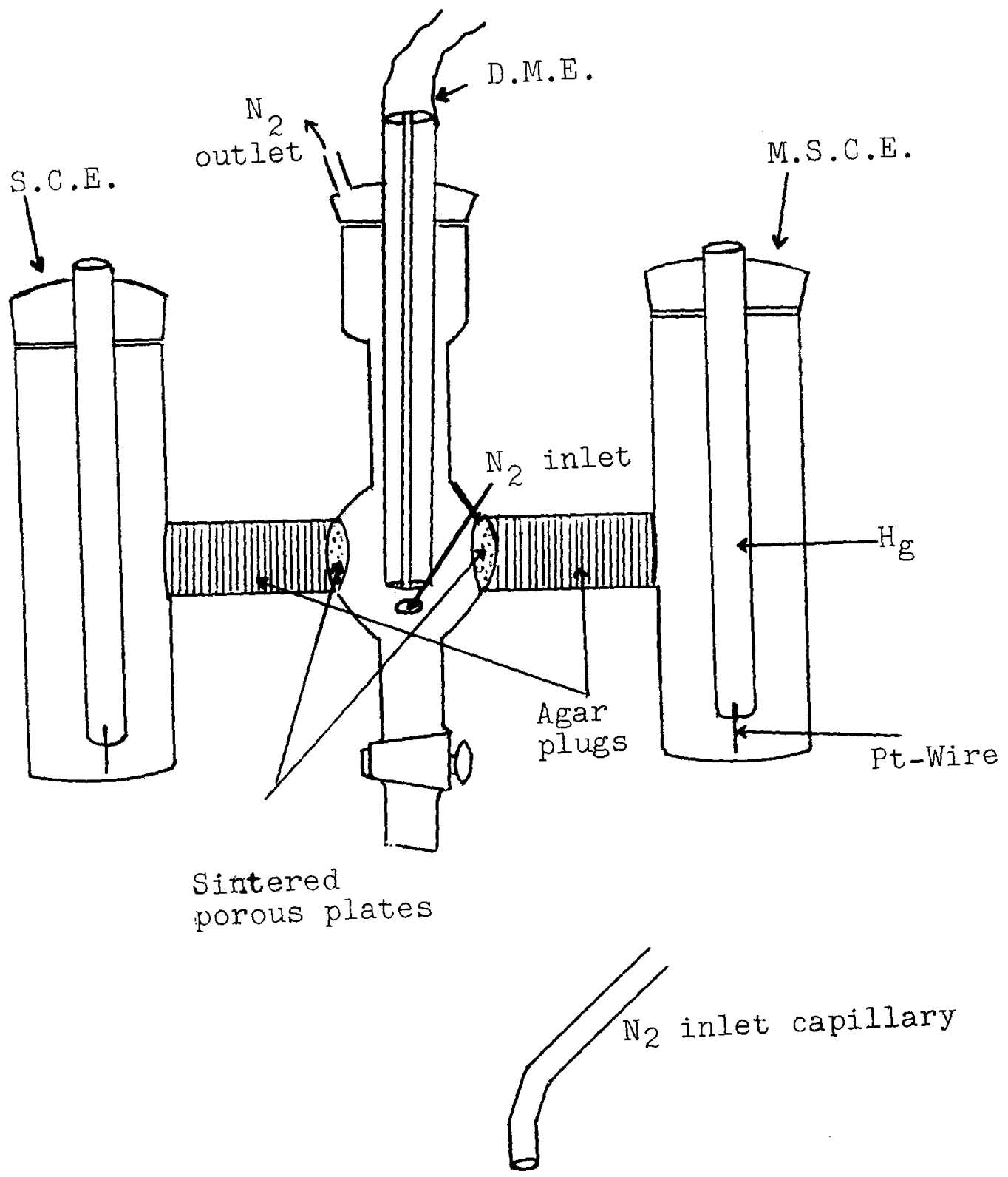
potential measurements were made with respect to an aqueous S.C.E. A Fluke Model 825 A Differential Voltmeter was used to measure the potential against the M.S.C.E.

All electrochemical experiments were carried out at $25 \pm 0.1^{\circ} \mathrm{C}$. The electrolyte used was $0.1 \mathrm{M} \mathrm{CH}_{3} \mathrm{COONa}$ in amhydrous methanol. The apparent $\mathrm{pH}$ of the solution was 9.7. The solutions were deaerated with nitrogen. The removal of residual oxygen from the nitrogen was accomplished by passing it through a train consisting of (in order) a bubbling tower filled with $\mathrm{I}: 1 \mathrm{NH}_{4} \mathrm{OH}$ and $\mathrm{H}_{2} \mathrm{O}$ (containing a few pieces of copper turnings and saturated with $\mathrm{NH}_{4} \mathrm{Cl}$ ), a tower filled with concentrated sulfuric acid; an empty trap and two towers containing electrolyte solution, the second having been immersed in water bath of $25^{\circ} \pm 0.10^{\circ} \mathrm{C}$. No damping was used in recording any of the polarograms. Methanol was purified by reflux and distillation from a magnesium-iodine solution at a high reflux ratio (34) .

The characteristics of the capillary used were: $\mathrm{m}=7.53 \mathrm{mg} \mathrm{sec}{ }^{-1} ; t=5.6 \mathrm{sec} ; \mathrm{m}^{2 / 3} \mathrm{t}^{1 / 6}=1.623$ $\mathrm{mg}^{2 / 3} \mathrm{sec}^{-\frac{1}{2}}$. The height of the mercury column was $53.5 \mathrm{~cm}$. stock solutions of beta-substituted phenylcystine derivatives were prepared by dilution of accurately weighed portions of the appropriate substituted phenylcystines. Solutions for electrochemical experiments were prepared 
using aliquots of the stock solution and dilution to the proper volume with stock electrolyte solution. No maximum suppressor was used in these studies. The diluted solutions were transferred to the polarographic cell, and deaerated for $15-30 \mathrm{~min}$. prior to recording of polarograms at $25 \pm 0.1^{\circ} \mathrm{C}$.

No correction for junction potentials have been made in this study. 
CHAPTER III

RESULTS

Polarographic Measurements of Some Beta-Substituted Phenylcystine Derivatives

Effect of Concentration on Diffusion Current

Polarograms for $\mathrm{N}$-benzoyl-threo- $\underline{\beta}-\underline{p}$-substituted phenylcystine ethyl ester in methanol with $0.1 \mathrm{M}$ sodium acetate as supporting electrolyte gave only one wave with the exception of the p-nitro derivative. In this case two waves were obtained. The first wave represented the reduction of the disulphide, while the second wave that of the nitro group. A linear relationship of the diffusion current to the concentration was obtained (Table IV and Figure 3). No prewave was observed as reported by Kalousek, et al. for the case of the polarographic reduction of cystines and $\underline{\alpha-s u b s t i t u t e d}$ cystines as shown by Thibert and Walton in aqueous medium (1, 35). Calculations of diffusion current was done by measuring the height, $h$, of the polarographic wave in millimeters (Figure 4) and substituting in the following equations:

$$
i_{\mathrm{d}}=\operatorname{sens} \cdot \mathrm{xh}
$$

Where $i_{d}=$ the diffusion current in $\mu a$

$$
\begin{aligned}
& \text { sens }=\text { the sensitivity in } \mu \mathrm{a} / \mathrm{mm} \\
& \mathrm{h}=\text { the wave height in } \mathrm{mm}
\end{aligned}
$$

e.g. Sens $=0.020 \mu \mathrm{a}$ per $\mathrm{mm}$

$$
\mathrm{h}=151 \mathrm{~mm}
$$

\section{4}


TABLE IV

EFFECT OF CONCENTRATION ON DIFFUSION CURRENT

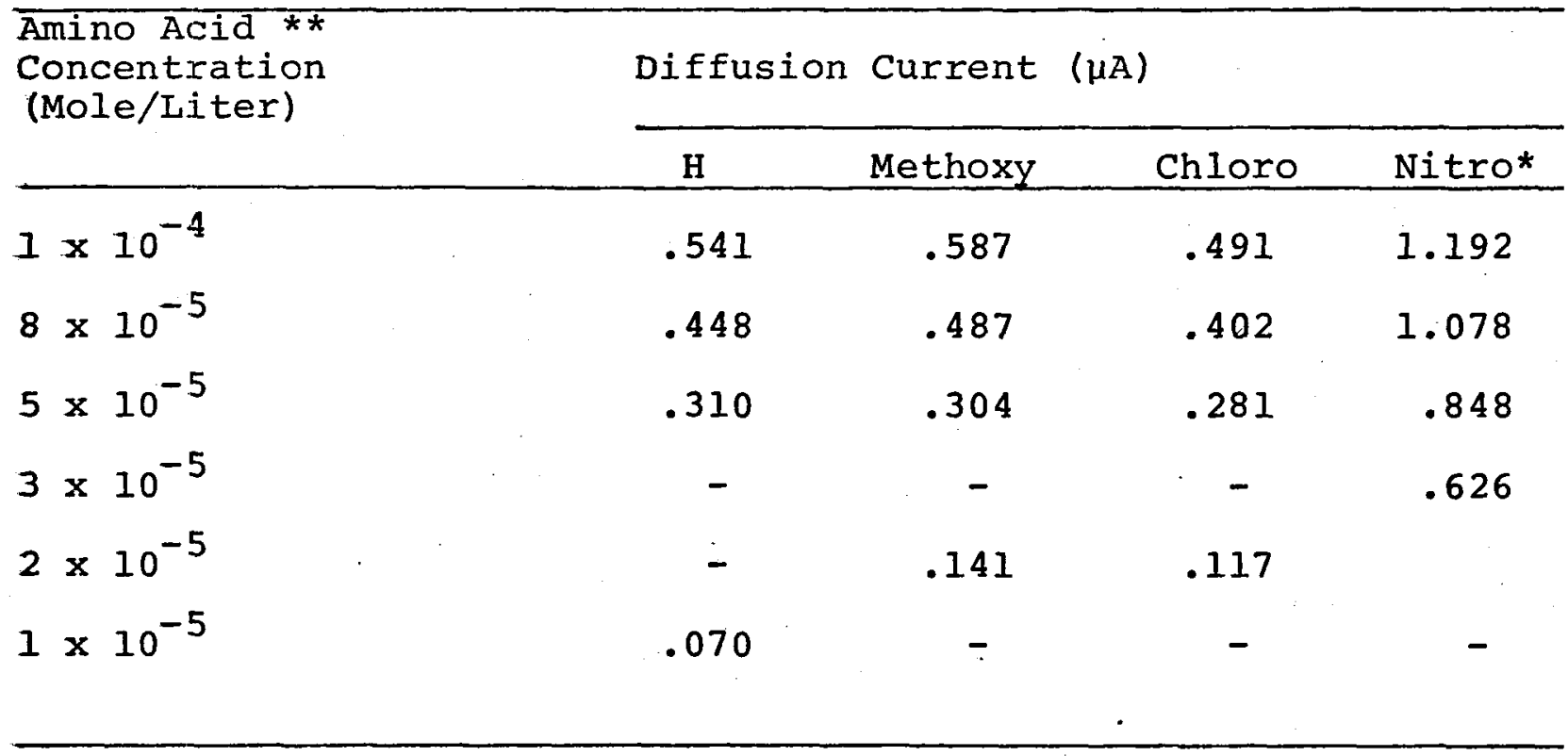

All the values are an average of three determinations.

*Diffusion current measured from the first wave

Amino acid - appropriate $\mathrm{N}$-benzoyl-threo- $\underline{\beta}-\underline{p}-$ substituted phenylcystine ethyl ester. 
FIGURE 3

EFFECT OF CONCENTRATION ON DIFFUSION CURRENT

\section{Legend}

Data for these plots are taken from current-voltage curves uncorrected for residual current.

Plots given are for (1) p-chloro-, (2) $\mathrm{H}-$, (3)

p-methoxy-, (4) p-nitro-substituted- $\underline{B}$-phenylcystine derivatives. 
FIGURE 3

EFFECT OF CONCENTRATION ON DIFFUSION CURRENT

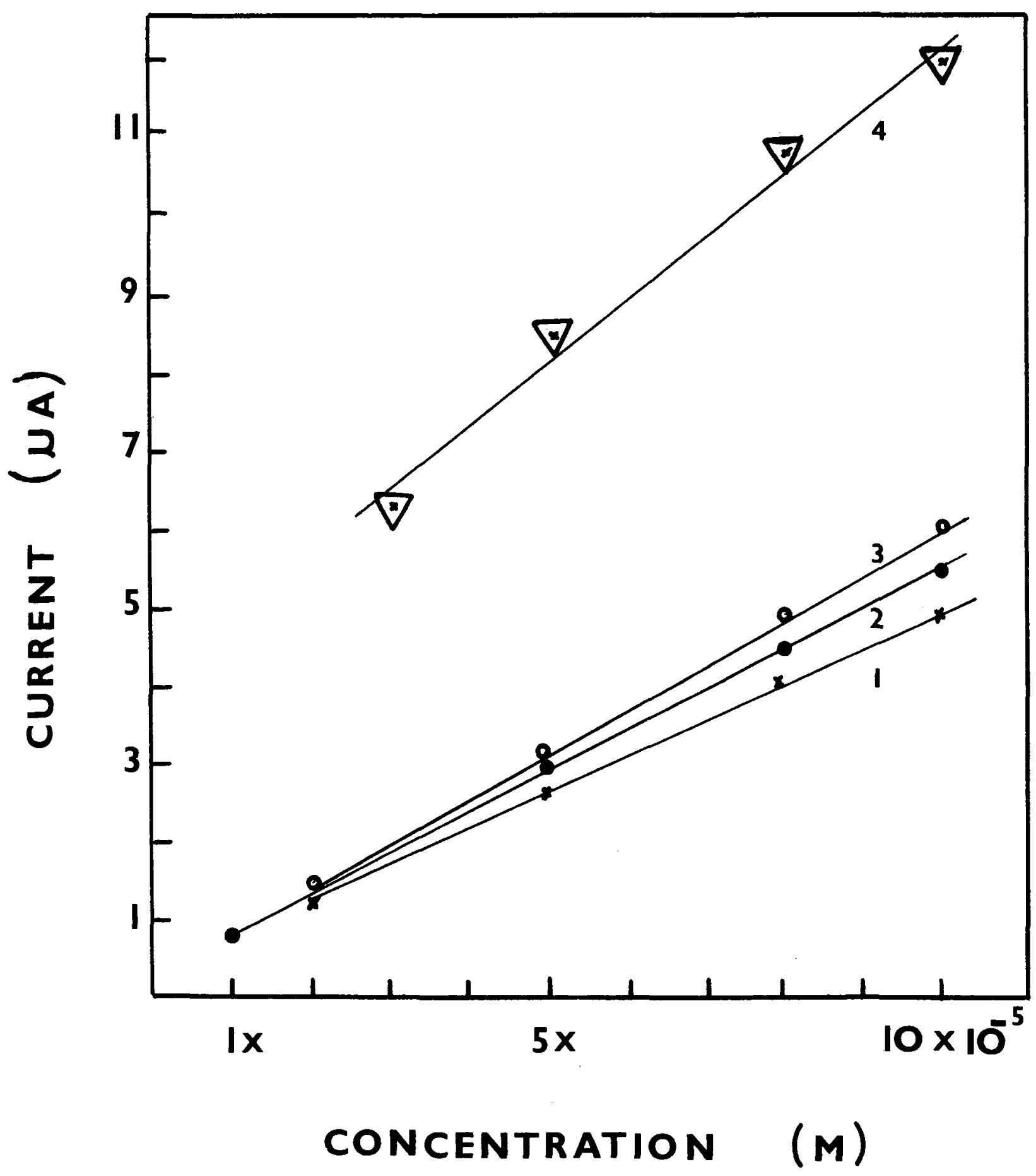




\section{FIGURE 4}

\section{TYPICAL POLAROGRAM}

\section{Legend}

A typical polarogram of $\mathrm{N}$-benzoyl-threo- $\underline{B}-\underline{\underline{P}}$ substituted phenylcystine ethyl ester in $0.1 \mathrm{M}$ sodium acetate-methanol. It shows the method by which the height, $h$, (diffusion current) and the apparent $E_{\frac{1}{2}}$ are measured. 
FIGURE 4

TYPICAL POLAROGRAM

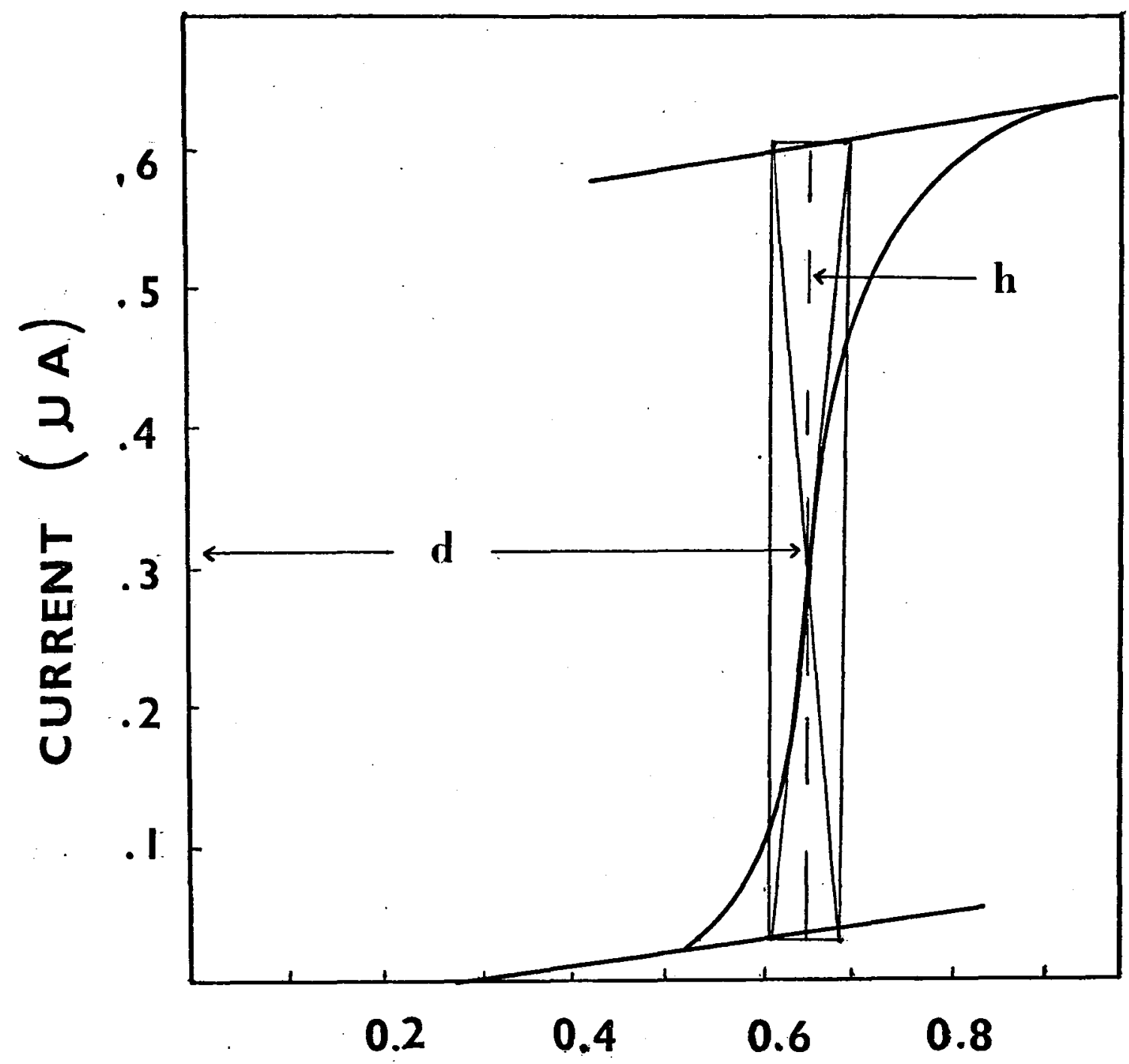

VOLTAGE V.S S.C.E. 
Therefore: $i_{d}=0.0020 \times 151$

$$
=0.302 \mu \mathrm{a} \text {. }
$$

The apparent half-wave potentials were calculated by measuring the distance in inches (d) from the beginning of the polarogram to the middle of the diffusion current wave curve (36) as shown in Figure 4.

These values were then substituted in equation 2:

$$
E_{\frac{1}{2}} \text { app. }=(-1 / 10) \times d
$$

Where $E_{\frac{1}{2}}$ app. = the apparent half-wave potential

$1 / 10=$ a const. for polarograph (since a polarogram is 10 inches long and the span used was 1 volt, therefore 1 inch represents 0.1 volt on the polarogram from the start ( 0 volt) of the span). The negative sign represents the negatively increasing voltage.

$d=$ the distance in inches from the start Therefore: if the polarogram was started at 0 volt and the $\mathrm{d}=6.38$ inches

$$
\text { The } \begin{aligned}
E_{\frac{1}{2}} \text { app } & =-.1 \times 6.38 \\
& =-0.638 \text { volt }
\end{aligned}
$$

The true half wave potentials were calculated according to the method of Taylor and Smith (37). All halfwave potential measurements were made with a manual arrangement, using a Fluke Model 825 A Differential voltmeter. The voltage was applied to the cell by means of the slide: wire of the Sargent Model XVI polarograph. The potentia]. 
of the dropping-mercury electrode (D.M.E.) with respect to the saturated calomel reference electrode (S.C.E) was measured with a precision Fluke differential voltmeter. The current and voltage were measured at a point about 0.1 volt or more, preceding the apparent half-wave potential to establish a zero point for the wave, and at appropriate voltage increments (of .05 V) up to and including the diffusion current plateau. Similar measurements were carried out on the supporting electrolyte solution alone. This value gave the residual current, which was then subtracted from the diffusion current readings (i). The diffusion current $i_{d}$ was then calculated. From these values of the current, $\log \frac{\left(i_{d}-i\right)}{i}$ values were calculated and plotted against the measured voltage. The value of $E$ at $\log \frac{\left(i_{d}-i\right)}{i}=0$ corresponds to the true half-wave potential, when the IR compensator is used in the circuit to correct for the in drop. Diffusion Coefficient and Reversibility of the Reaction

The diffusion current obtained at the D.M.E. under controlled (36) conditions is dependent on diffusion and electrolysis factors. The diffusion parameter includes temperature, viscosity, ionic mobility, the area and drop rate of the mercury. Ilkovic has developed the following equation for the polarographic diffusion current under constant conditions: 


$$
i_{d}=607 \cdot n \cdot D^{\frac{1}{2}} \cdot S \cdot m^{2 / 3} \cdot t^{1 / 6}
$$

Where $i_{\mathrm{d}}=$ the average current in microamperes

$$
\begin{aligned}
\mathrm{n}= & \text { number of faraday required per mole of } \\
& \text { electroactive species } \\
\mathrm{D}= & \text { the diffusion coefficient of the species } \\
& \text { in } \mathrm{cm}^{2} \mathrm{sec}^{-1} \\
\mathrm{C}= & \text { concentration of the substance in milli- } \\
& \text { moles per liter } \\
\mathrm{m}= & \text { the rate of flow of mercury in milligrams } \\
t= & \text { per second }
\end{aligned}
$$

Table $V$ illustrates the diffusion coefficients of phenyl$\underline{\underline{p}}$-methoxyphenyl-, $\underline{p}$-chlorophenyl-, and $\underline{p}$-nitrophenyl- $\underline{\beta}-$ substituted cystine derivatives calculated by the use of the Ilkovic equation.

In order to determine the number of electrons consumed in the electrode process and to demonstrate the reversibility of the system, the so-called logarithmic analysis of the current-voltage curve was carried out. The equation of the polarographic curve for a cathodic reduction may be written as $(14,44)$.

$$
E_{\text {D.M.E. }}=E_{O .5}+\frac{0.0591}{n} \log \left(i_{d^{-i}}\right) / i^{2} \text { at } 25^{\circ} \mathrm{C}
$$

It follows from this equation that the dependence of 
TABLE V

DIFFUSION COEFFICIENT

\begin{tabular}{lcc}
\hline $\begin{array}{l}\text { Amino Acid } \\
\text { Substituent } \\
\text { Group }\end{array}$ & $\begin{array}{c}\text { Diffusion } \\
\text { Current } \\
(\mu a)\end{array}$ & $\begin{array}{l}\text { Diffusion } \\
\text { Coefficient } \\
\left(\mathrm{cm}^{2} \text { sec }_{\mathrm{X}}{ }^{6}\right)\end{array}$ \\
\hline $\mathrm{H}$ & .276 & 7.84 \\
$\mathrm{CH}_{3} \mathrm{O}$ & .258 & 6.85 \\
$\mathrm{Cl}$ & .256 & 6.74 \\
$\mathrm{NO}_{2}$ & .730 & 54.89 \\
\hline
\end{tabular}

The amino (0.1M) acid concentration was $5 \times 10^{-5} \mathrm{M}$. Sodium acetate in methanol was used as the supporting electrolyte. 
$\log \left(i_{d}-i\right) / i^{2}$ on the potential $E$ must be a straight line with a slope of $29.5 \mathrm{mV}$. Figure 5 shows that all of the amino acids give straight lines. The slopes of these plots are given in Table VI. Table VIIgives the values of $E$ vs. $\log \left(i_{d}-i\right) / i^{2}$

Half-Wave Potential

Corrected half-wave potentials for the amino acids, phenyl-, $\mathrm{p}^{-m e t h o x y p h e n y l-,} \mathrm{p}$-chlorophenyl- and $\mathrm{p}$-nitrophenylcystine derivatives are given in Table VIII Determination of half-wave potential was carried out after subtraction for residual current. Plots of $E$ versus $\log \left(i_{d}-i\right) / i$ were drawn and the $E_{\frac{1}{2}}$ determined (See Figure 6). $(1,44)$.

Ultraviolet spectra

The wave lengths of the $N$-benzoyl-threo- $\underline{B}-\underline{p}-s u b-$ stituted phenylcystine derivatives were measured in methanol. $\alpha$-substituted cystines were dissolved and their ultraviolet spectra were measured. Absorption data are listed in Table IX plots of $E_{\frac{1}{2}}$ versus $m \mu$ were not made since the deviation between these values were not large. 


$$
\begin{gathered}
\text { FIGURE } 5 \\
\text { PLOT OF LOG }\left(i_{\mathrm{d}}-i\right) / i^{2} \text { VS. VOLTAGE }
\end{gathered}
$$

\section{Iegend}

Data for these plots were taken from currentvoltage curves corrected for residual current. The concentration of the amino acids was $t \times 10^{-5} \mathrm{M}$. Plots are drawn for the $\mathrm{N}$-benzoyl-threo- $\underline{-}-\underline{p}-$-substitutedphenylcystine ethyl ester where (O) represents phenyl-, (A) p-methoxyphenyl-; (x) p-chlorophenyl-, and (0) p-nitrophenyl-substituents. The polarograms were run using $0.1 \mathrm{M}$ sodium acetate in methanol as the supporting electrolyte. 

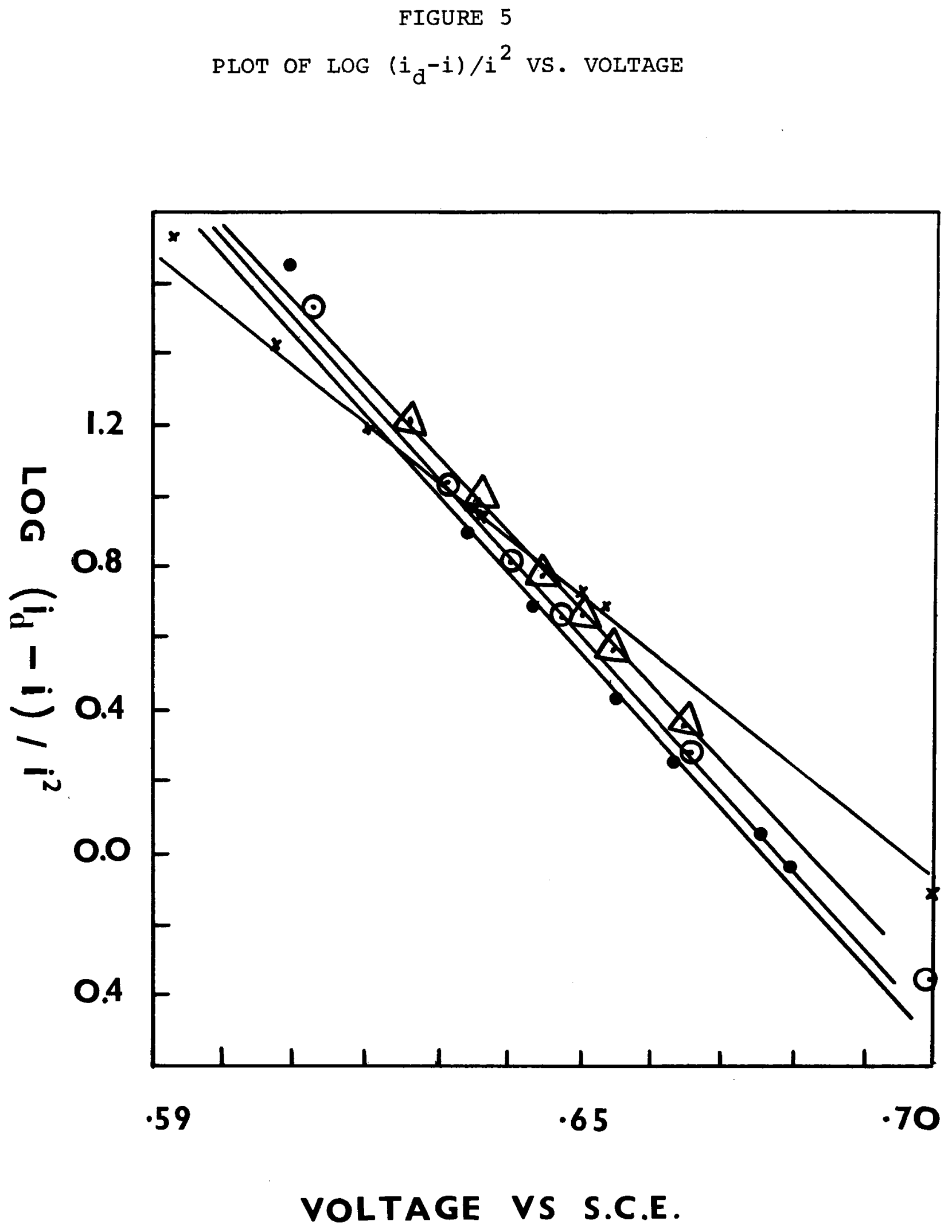
TABLE VI

SLOPE OF E VS. $\log \left(i_{d}-i\right) / i^{2}$ PLOT

Amino Acid

Slope

$\left(5 \times 10^{-5} \mathrm{M}\right)$

(Volts)

$\mathrm{N}$-Benzoyl-threo- $\beta$-phenyl-

cystine ethyl ester

0.0246

N-Benzoyl-threo- $\beta-$

p-methoxyphenylcystine

ethyl ester

0.0208 .

N-Benzoyl-threo-B-p-

chlorophenylcystine

ethyl ester

0.0185

N-Benzoyl-threo- $\underline{-}-\underline{p}-$

nitropheny lcystine

ethyl ester

0.0212 
TABLE VII

VALUES OF E AND $\log \left(i_{d^{-i}}\right) / i^{2}$

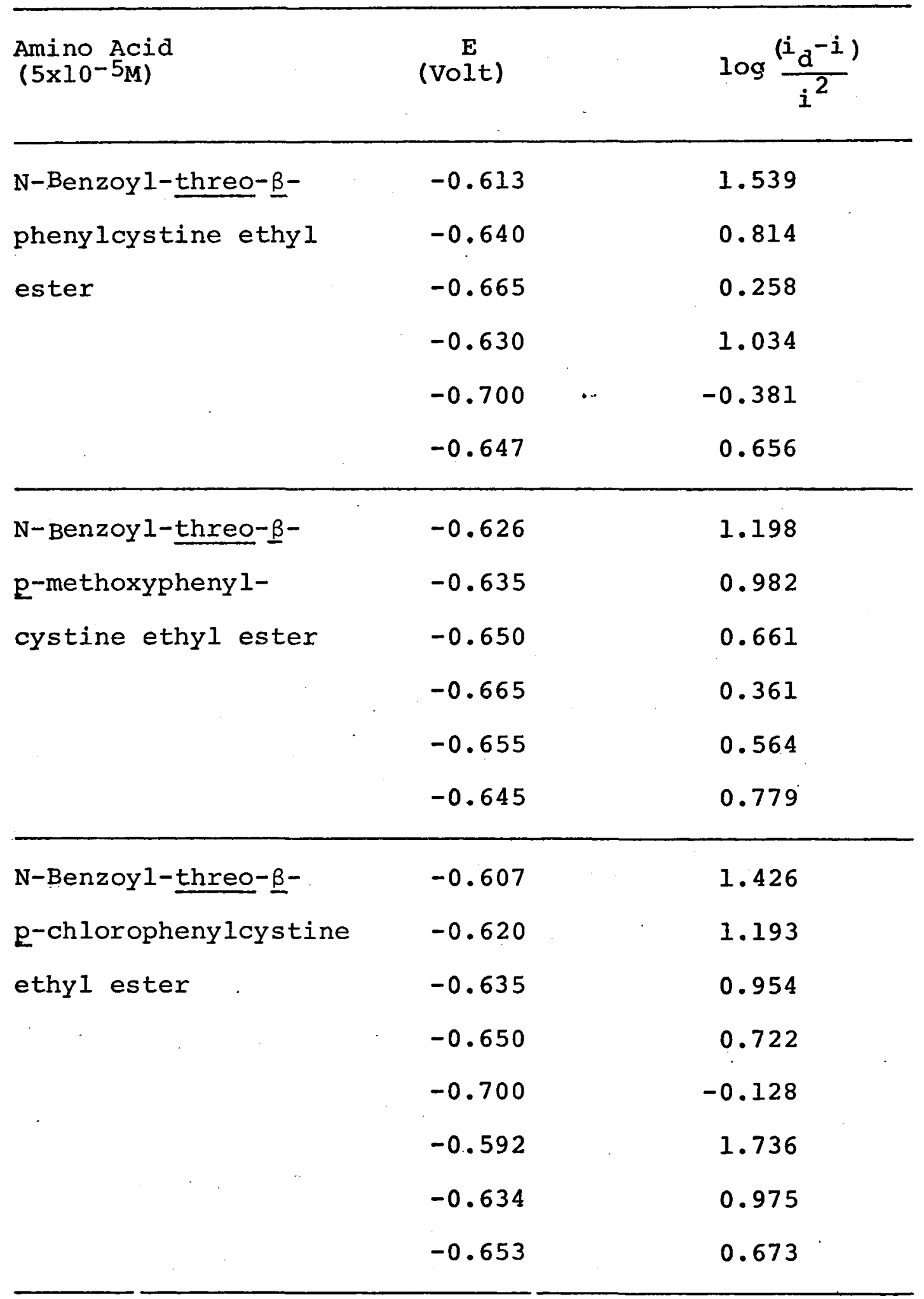


TABLE VII (Continued)

\begin{tabular}{lcc}
\hline $\begin{array}{l}\text { Amino_Acid } \\
\left(5 \times 10^{-5}\right)^{-}\end{array}$ & $\begin{array}{c}E \\
(\text { Volt })\end{array}$ & $\log \frac{\left(i d^{-i}\right)}{i^{2}}$ \\
\hline N-Benzoyl-threo- - & -0.609 & 1.651 \\
p-nitrophenylcystine & -0.629 & 1.072 \\
ethyl ester & -0.643 & 0.679 \\
& -0.663 & 0.256 \\
& -0.679 & -0.036 \\
& -0.634 & 0.885 \\
& -0.675 & 0.035 \\
& -0.655 & 0.420 \\
\hline
\end{tabular}


TABLE VIII

HALF-WAVE POTENTIAL

Amino Acid

Half-Wave Potential

(Volt)

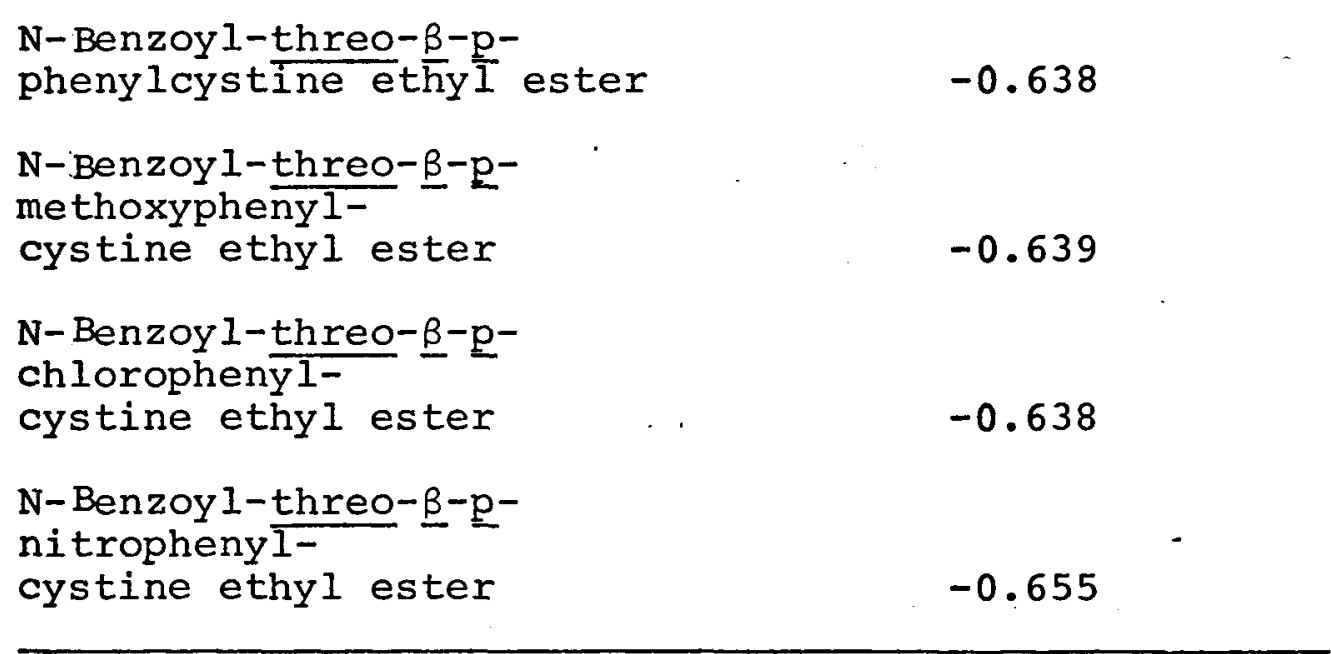


FIGURE 6

PLOT OF LOG $\left(i_{\mathrm{d}^{-i}}\right) / i$ VS. E.

Legend

Data for these plots were taken from currentvoltage curves. The values are all corrected for the residual current. Concentration of the amino acids used were $5 \times 10^{-5} \mathrm{M}$ using $0.1 \mathrm{M}$ sodium acetate in methanol as the supporting electrolyte. Plots represent phenyl- $(x), \underline{p}-m e t h o x y p h e n y l-(\boldsymbol{O}), \mathrm{p}^{-}$

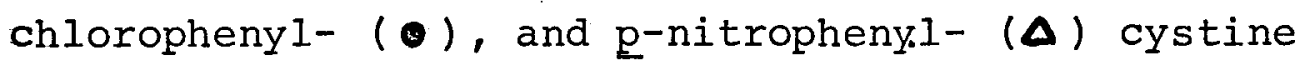
derivatives. 
FIGURE 6

PLOT OF LOG $\left(i_{\left.d^{-i}\right) / i}\right.$ VS. E.

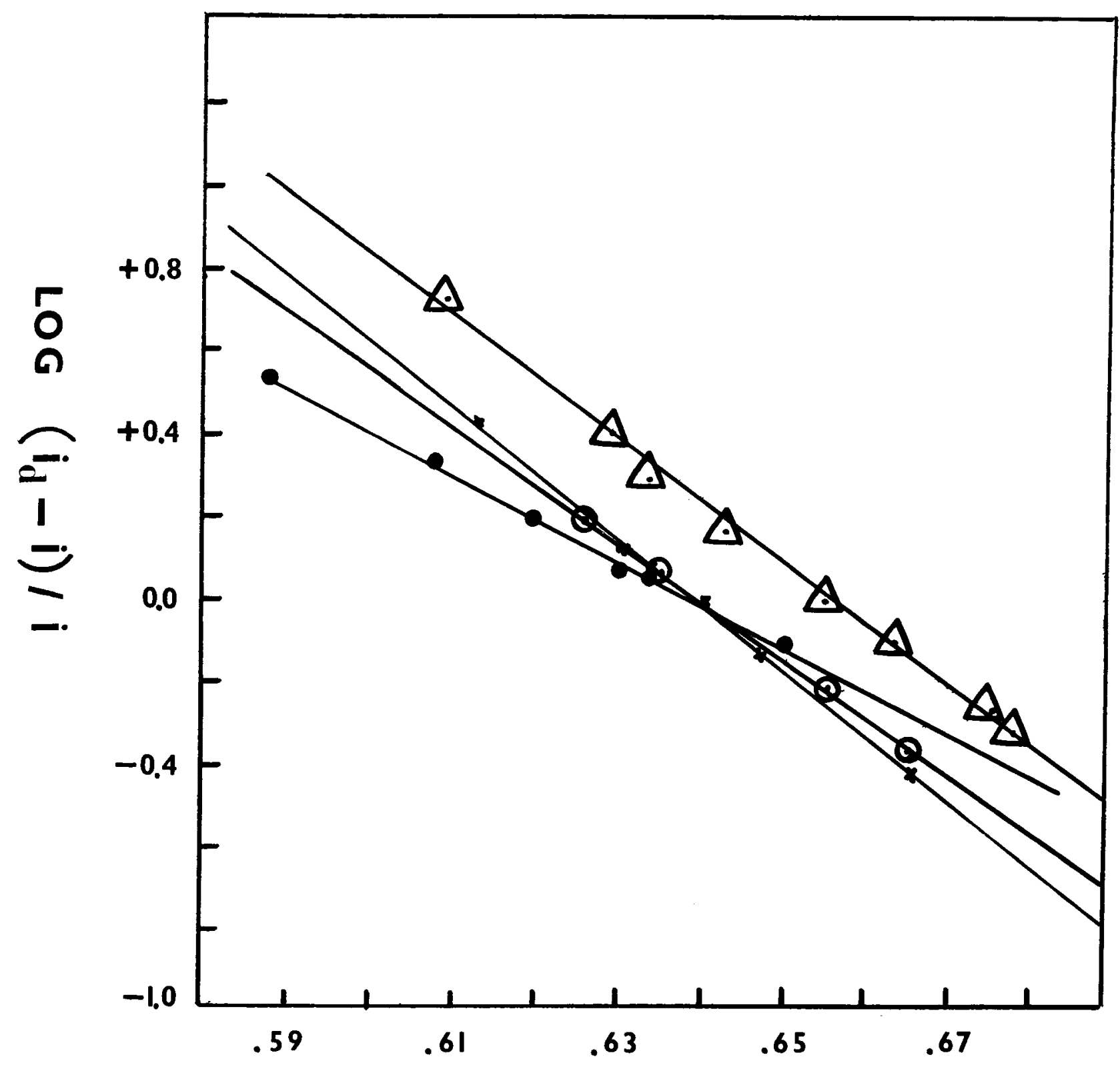

VOLTAGE VS S.C.E. 
TABLE IX

ABSORPTION CHARACTERISTICS OF SOME AMINO ACID AND DERIVATIVES*

\begin{tabular}{lll}
\hline Amino Acid* & $\lambda_{\max (\mathrm{m} \mu)}$ & Solvent \\
\hline$\underline{\alpha-M e t h y l c y s t i n e}$ & 208 & $0.1 \mathrm{~N} \mathrm{HCl}$ \\
$\underline{\alpha-E t h y l c y s t i n e}$ & 207 & $0.1 \mathrm{~N} \mathrm{HCl}$ \\
a-n-Propylcystine & 205 & $0.1 \mathrm{~N} \mathrm{HCl}$ \\
$\underline{\alpha-I s o p r o p y l c y s t i n e}$ & 207 & $0.1 \mathrm{~N} \mathrm{HCl}$ \\
$\underline{\alpha-n-B u t y l c y s t i n e}$ & 207 & $0.1 \mathrm{~N} \mathrm{HCl}$ \\
$\underline{\alpha-P h e n y l c y s t i n e}$ & 208 & $0.1 \mathrm{~N} \mathrm{HCl}$ \\
B-phenyl- & 180 & methanol \\
B-p-Methoxyphenyl- & 181 & methanol \\
B-p-Chlorophenyl- & 180 & methanol \\
$\underline{\text { B-p-Nitrophenyl- }}$ & 182 & methanol \\
\hline
\end{tabular}

* Amino acid derivatives - appropriate $\mathrm{N}$-benzoyl-threo$\underline{B}-\underline{p}$-substituted cystine ethyl ester. 
CHAPTER IV

DISCUSSION

\section{A. Synthesis of $\beta$-p-Substituted Phenylcystine Derivatives}

A considerable amount of work has been carried out by Heilbron and co-workers (38-43) on the synthesis of analogues of $\mathrm{N}$-benzoyl-threo-B-phenylcysteine ethyl ester. Figures 7 and 8 illustrate the pathways by which they synthesized substituted phenylcysteines. A good yield of 2-mercapto thiazolone (See Figure 8), which would have been the starting material for the preparation of substituted phenylcysteine derivatives, was not obtained. Both pathways gave poor yields. Among the projects rejected by Heilbron was an attempt to condense thioacetic acid with ethyl acetamidocinnamate. This was due to the low reactivity of thioacetic acid towards double bonds. Thiobenzoic acid does form an adduct but in poor yield. Sicher and co-workers (23) have demonstrated that dichlorothioacetic acid, which has a higher activity towards double bonds, forms very easily an adduct with ethyl- $\underline{\alpha-b e n z a m i d o c i n n a m a t e . ~ T h e y ~}$ have prepared substituted $\mathrm{N}$-benzoyl-threo-B-phenylcysteine ethyl ester via $\Delta^{2}$-oxazolines which were prepared from 1 , 2-aminoalcohols.

Exlenmeyer and co-workers (25-29) have used a general 
FIGURE 7

$$
\begin{aligned}
& \mathrm{NH}_{2} \mathrm{CH}_{2} \mathrm{COOH} \stackrel{\mathrm{KOH}}{\longrightarrow} \mathrm{NH}_{2} \mathrm{CH}_{2} \mathrm{COOK} \underset{\mathrm{CK}}{\stackrel{\mathrm{KOH}}{\mathrm{CS}_{2}}} \underset{l_{2}}{\mathrm{C}}-\mathrm{NHCH}_{2}-\mathrm{COOK} \\
& \text { Glycine } \\
& \downarrow \mathrm{C}_{2}{ }^{\mathrm{H}} 5^{\mathrm{Br}}
\end{aligned}
$$

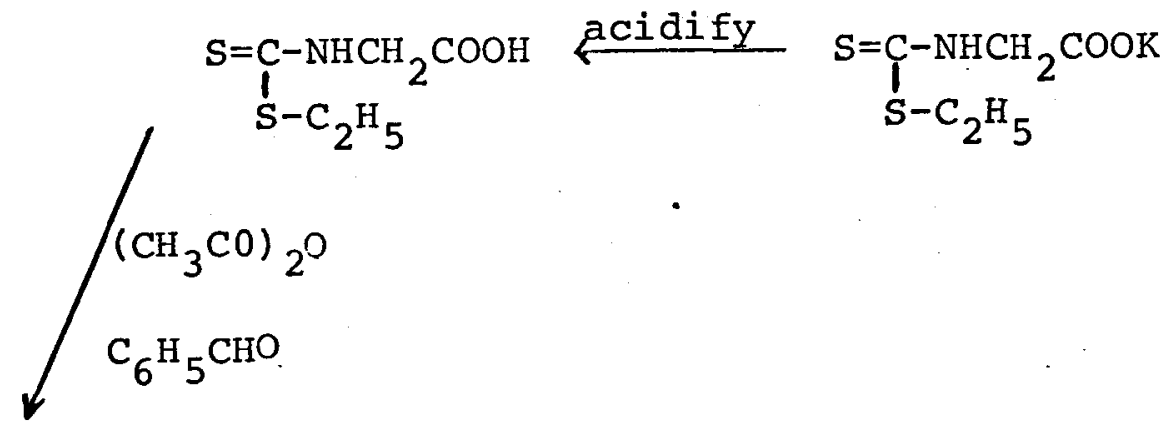<smiles>O=C1SC(S)=NC1=Cc1ccccc1</smiles>

Thiazolone

4- Benzylidene-2thiazolone

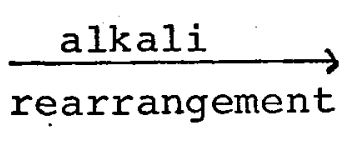<smiles>O=C(O)C1C2SC3(S)SC(S)(C3S)N21</smiles>

Thiazoline

$$
\begin{aligned}
& \mathrm{HCl}, 100^{\circ} \mathrm{C} \\
& \text { sealed tube } \\
& \mathrm{C}_{6} \mathrm{H}_{5}-\mathrm{CH}-\mathrm{CH}_{\mathrm{SH}} \mathrm{COOH} \\
& \mathrm{NH}_{2}
\end{aligned}
$$

B-Phenylcysteine 
FIGURE 8

$\mathrm{NH}_{2} \mathrm{CH}_{2}-\prod_{\mathrm{C}-\mathrm{NH}_{2}}+\mathrm{KOH}$ Aminoacetamide

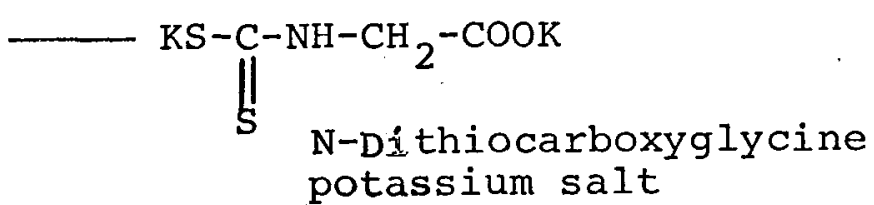
potassium salt

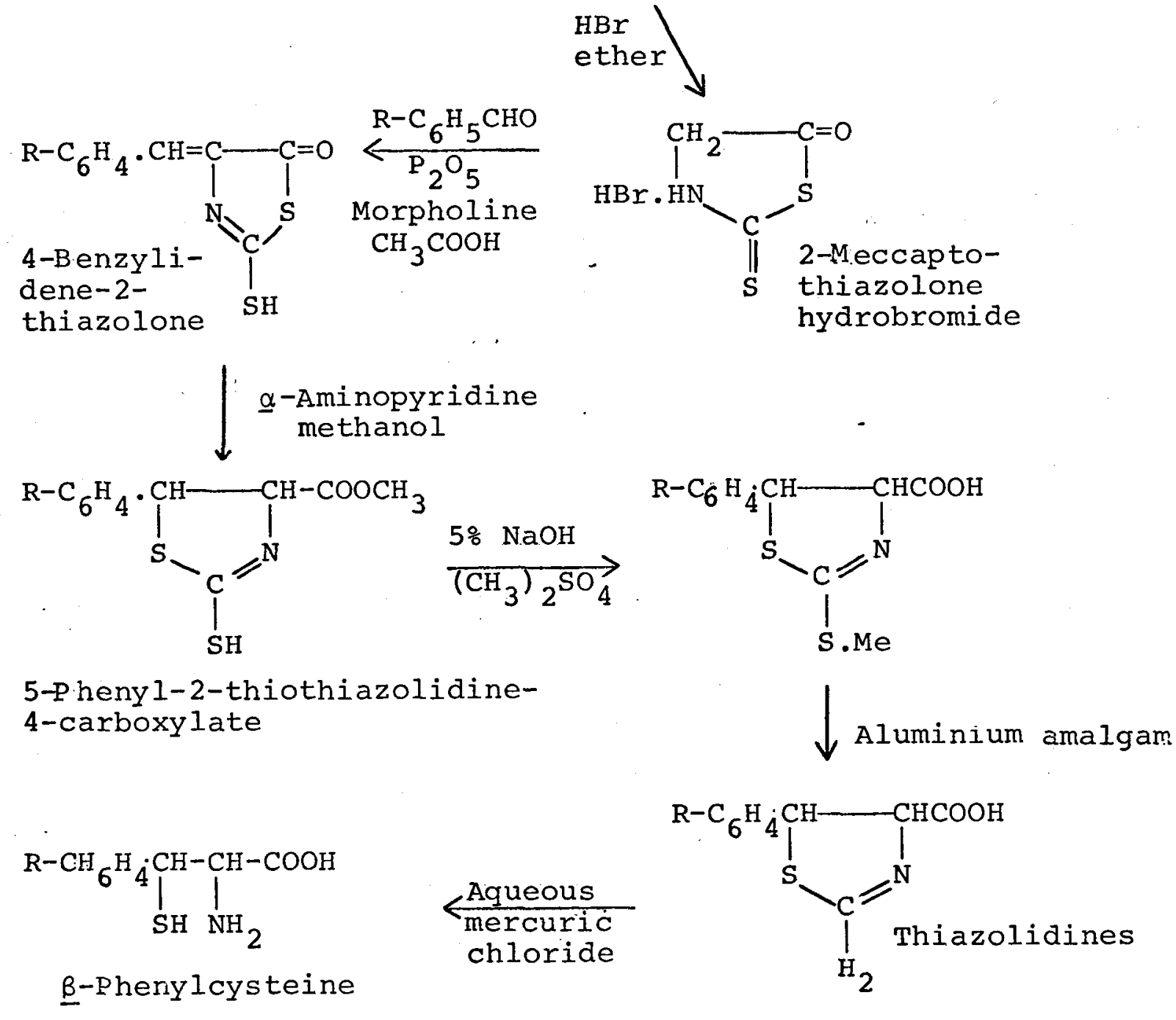


condensation reaction between aldehydes or ketones and compounds containing activated methylene groups in the presence of an organic base, to synthesize oxazolones. Treatment of oxazolones with concentrated sulphuric acid and ethanol gave the $\underline{\alpha}, \underline{\beta}$-unsaturated compounds. In this synthesis, hippuric acid in presence of sodium acetate, acetic anhydride and para-substituted benzaldehydes were used to prepare substituted oxazolones. Para-substituted$\underline{\alpha-b e n z a m i d o c i n n a m i c ~ a c i d ~ e t h y l ~ e s t e r s ~ w e r e ~ s y n t h e s i z e d ~}$ from these oxazolones (See Figurel).

The condensation of dichlorothioacetic acid with these substituted cinnamates was accomplished with 40-47\% yield. The constitution and configuration of S-dichloroacety $1-\mathrm{N}$-benzoyl- $\beta$-phenylcysteine ethyl ester has been proved by sicher and co-workers (23) by alcoholysis-and acetylation of the latter compound.

The reduction of the adduct was accomplished by the Meerwein-Ponndorf-Verley reaction (30) which uses aluminium isopropoxide. The yields obtained were satisfactory (70\%). The mechanism of these reactions have been discussed in the literature (30).

The synthesis of cystine derivatives was accomplished by oxidation of cysteine derivatives with $0.2 \mathrm{~N}$ iodine solution in dioxane. Yields varied from 40-85\% for the various compounds synthesized. The poor yields were due to large losses during recrystallization steps. No attempt was. made to recover the material from the mother-liquor: 
The above procedure was found to be more advantageous for the preparation of $\mathrm{N}$-benzoyl-threo- $\mathrm{B}-\mathrm{p}-$ substutited-phenylcysteine ethyl esters, than the ones from Heilbron and co-workérs. $(38-43)$.

B. Polarographic Investigation of B-Substituted Phenylcystine Derivatives

A quantitative method for the determination of derivatives of substituted phenylcysteines and cystines was developed using a modified procedure of Thibert et al. $(18,19)$ which gave molecular weights within \pm 2 응 These results were not reported here; since only a duplicate analysis was run on some of them.

A quantitative polarographic method was thought to be feasible due to previous work with alpha-substituted cystines (1). Diffusion current plots vs. concentration showed a linear relationship. This indicated that a rapid and accurate polarographic determination can be carried out without any complication using $0.1 \mathrm{M}$ sodium acetate in methanol as the supporting electrolyte at an apparent $\mathrm{pH} 9.7$.

No $\mathrm{pH}$ dependency studies were carried out, since a nonaqueous medium was used. Only the apparent pH of the supporting electrolyte was measured. No maxima were observed on the polarograms, therefore, no maximum suppressor was used. The shapes of the polarograms were similar, without a prewave, to the case of cystine and alpha-substituted cystines except that the latter had a 
prewave $(1,35)$.

In order to determine whether the reduction of substituted $\underline{\beta}$-phenylcystine derivatives was reversible, plots of $E$ vs $\log \left(i_{d}-i\right) / i^{2}$ were made (See Figure 5). All of the amino acid derivatives gave a straight line whose slopes are given in Table VI. Values ranging from 0.0246-0.0185 were obtained (Figure 5). The theoretical slope of 0.0295 indicates a reversible reduction reaction involving two electrons. Experimental values are not very close to the theoretical values and so one can predict, a nonreversible reduction reaction in case of these substituted amino acids except in the case of $\mathrm{N}$-benzoyl-threo- - -phenylcystine ethyl ester.

Diffusion coefficients were calculated by substitution of the experimental values into Ilkovic's equation. Table $V$ shows values which lie between $6.75-7.85 \times 10^{-6}$ $\mathrm{cm}^{2} \sec ^{-1} \times 10^{6}$ for phenyl-, p-methoxyphenyl- and p-chlorophenylcystine derivatives, while $5.489 \times 10^{-7} \mathrm{~cm}^{2} \sec x$ $10^{6}$ was found for the p-nitrophenylcystine derivative. The value reported for cystine is $5.70 \times 10^{-6} \mathrm{~cm}^{2} \mathrm{sec}^{-1} \mathrm{x}$ $10^{6}$, which is less than that of $\underline{\beta}$-substituted phenylcystine derivatives. Alpha-substituted cystines have diffusion coefficients in the range of $4.87-3.27 \times 10^{-6} \mathrm{~cm}^{2} \mathrm{sec}^{-1} \mathrm{x}$ $10^{6}$, which is less than cystine as well as $\underline{\beta}$-substituted phenylcystine derivatives. This could be due to the difference in structure and the use cif a non-aqueous medium. 
Thus far, the discussion has been mainly concerned with polarographic determinations. Consideration will now be given to the correlation between reaction rate, half-wave potential and the structure of the substituent (the substituent constant - $\underline{0}$ ). Hammett (8) has defined the substituent constant by the following equation:

$$
\log \mathrm{k} / \mathrm{k}^{\mathrm{o}}=\underline{\sigma \rho}
$$

where $k$ is the dissociation constant of substituted benzoic acids and $\mathrm{k}^{\circ}$ is the dissociation constant of benzoic acid.

$\underline{\rho}=$ the reaction constant, which depends on the reaction, the condition, and the nature of the side chain.

It is preferable to compare the rates of the series of reactions with the equilibrium constants of the same series. Since ionization constants are proportional to the equilibrium constants, they could be substituted for equilibrium constants. However, the substituent constants for a particular electron-withdrawing group, applicable to most reactions, does not give good results when used with reactions of other series. Therefore, special substituent constants have been defined by Jaffe (9) and Taft and Lewis (7) .

In this study, for the comparison of the effect of substituents on the reduction of cystines, two model compound systems were selected. Equilibritm constants in the two series-ethyl p-substituted phenyl acetate and ethyl p- 
substituted cinnamates - were taken from the data of alkaline hydrolysis of these esters (45).

Table $\mathrm{X}$ and Figure 9 shows the large changes in reaction rate and equilibrium constants of these esters due to the substituent effect. They correlate quite satisfactorily. No polarographic data were available for this series, which enable us to compare the data of these esters with $\mathrm{N}$-benzoy $\mathrm{I}-\underline{B}-\underline{p}$-substituted cystine ethyl esters. p-Phenyl-, p-methoxyphenyl-, p-chlorophenyl- and p-nitrophenylcystine ethyl esters show very little difference (ca $17 \mathrm{mV}$ ) between their half-wave potentials. However, a strong electron withdrawing group (like $\mathrm{NO}_{2}$ ) is required to show this small ( $17 \mathrm{mV}$ ) change in half-wave potential. One can, therefore, conclude (Figure 10; Table XI) that there is no apparent correlation between half-wave potential and the structure of the substituent (substituent constants $\underline{\sigma}^{*}$ ). There is a possibility that the value of the p-chlorc- derivative is lower than one would expect.

In order to show that $E_{\frac{1}{2}}$ values might bear some significant relationship to spectroscopic data (UV), the spectra of these cystine derivatives were measured in methanol. Since no appreciable differences in the wave length of the ajsorption maxima or shoulders as a function of half-wave potentials were found, no correlationship study for these values were carried out (See Tabie IX). 
TABLE $\mathrm{X}$

EQUILIBRIUM CONSTANTS OF p-SUBSTITUTED PHENYL ACETATE AND p-SUBSTITUTED CINNAMATES*

\begin{tabular}{llcc}
\hline Acid & $\mathrm{k}$ & $\underline{\sigma}{ }$ & log $\mathrm{k}$ \\
\hline Ethyl phenyl acetate & 0.639 & 0.00 & -.1945 \\
Ethyl p-methoxyphenyl acetate & 0.580 & -0.27 & -.2366 \\
Ethyl p-chlorophenyl acetate & 1.62 & +0.23 & +.2095 \\
Ethyl p-nitrophenyl acetate & 4.57 & +0.78 & +.6599 \\
Ethyl p-aminophenyl acetate & $0.325^{\circ}$ & -0.66 & -.4881 \\
Ethyl cinnamate & 0.106 & 0.00 & -.9747 \\
Ethyl p-methoxycinnamate & 0.0444 & -0.27 & -2.3526 \\
Ethyl p-chlorocinnamate & 0.215 & +0.23 & -.6676 \\
Ethyl p-nitrocinnamate & 1.037 & +0.78 & +.0161 \\
Ethyl p-methylcinnamate & 0.0754 & -0.17 & -2.1226 \\
\hline
\end{tabular}




$$
\begin{gathered}
\text { FIGURE ' } 9 \\
\text { PLOT OF LOG } k \text { VS. LOG } k
\end{gathered}
$$

FOR ETHYI p-SUBSTITUTED PHENYLACETATE

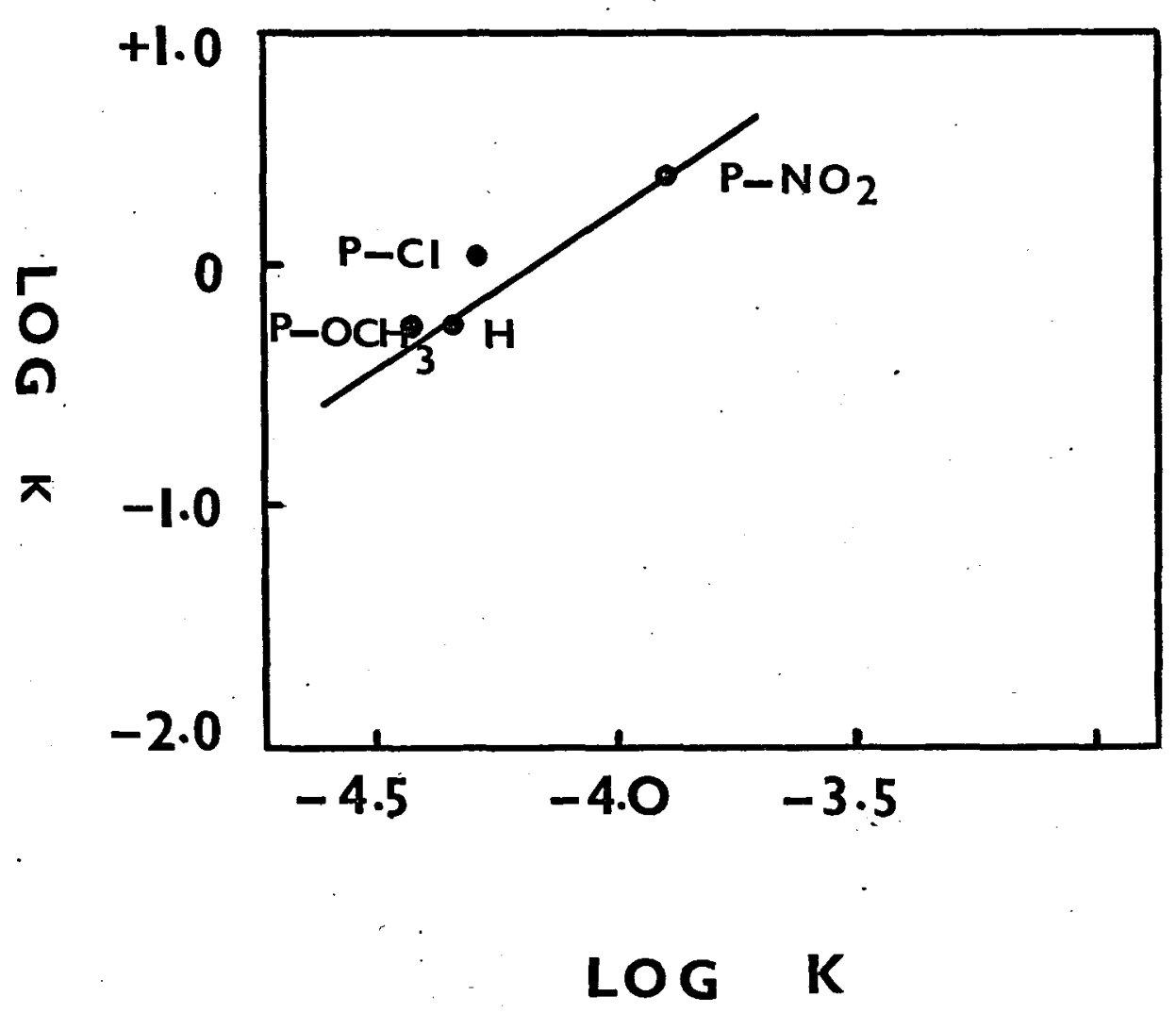


FIGURE 10

$$
\text { PLOT OF } E_{\frac{1}{2}} \text { VS. } \underline{\sigma}^{*} \text { AND } \underline{\sigma}_{I}
$$

\section{Legend}

Data for these plots are taken from half-wave potentials and Taft values $(7,8)$.

Plots are given for phenyl-, p-methoxyphenyl-, p-chlorophenyl- and p-nitrophenylcystine derivatives.

(•) represents $\underline{\sigma}_{I}$ and (०) represents $\underline{\sigma}^{*}$ values. 
FIGURE 10

PLOTS OF $E_{1 / 2}$ Vs. $\underline{\sigma}^{*}$ AND $\underline{\sigma}_{I}$

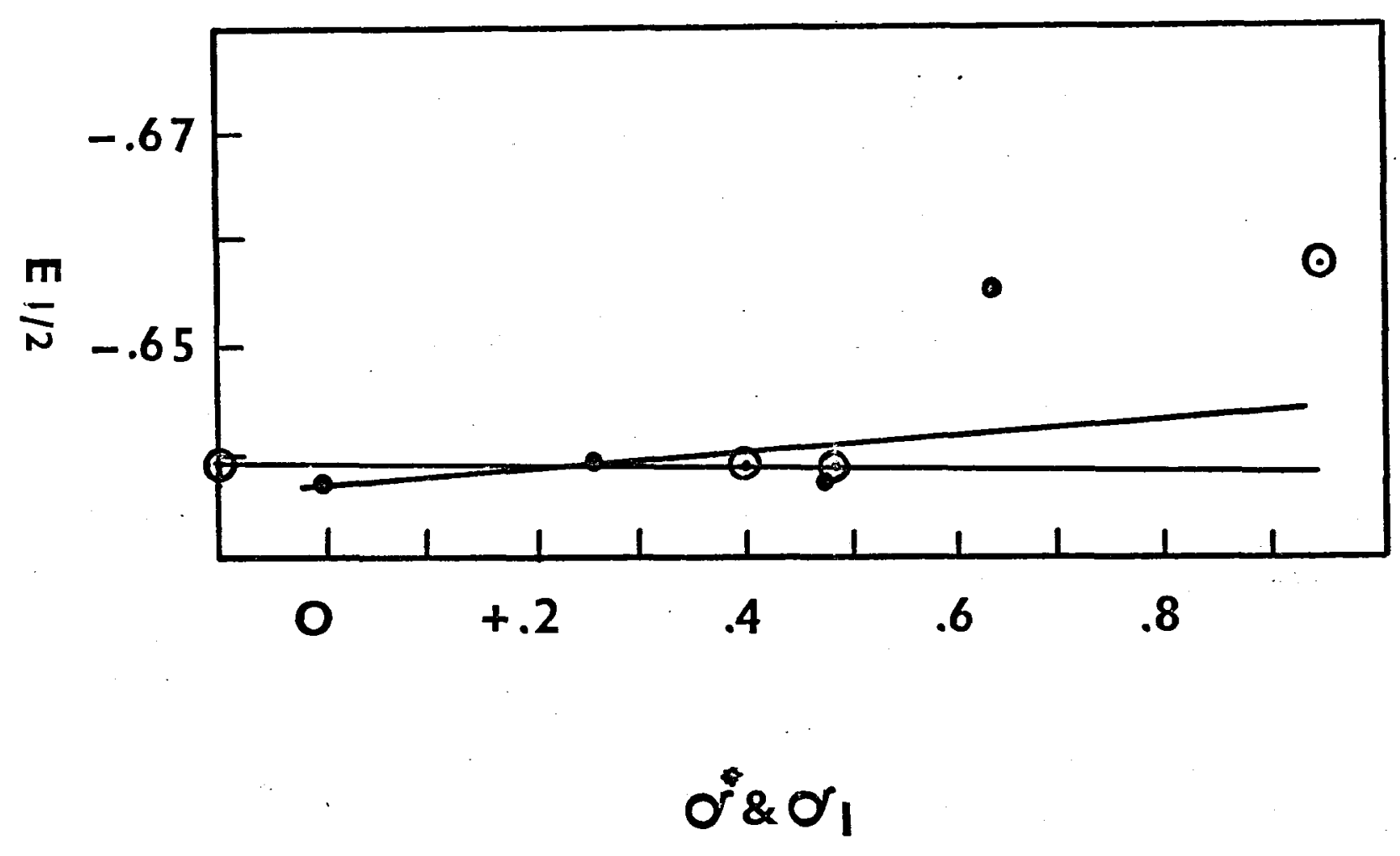


TABLE XI

HALF-WAVE POTENTIALS AND $\underline{\sigma}_{I} ; \underline{\sigma}^{*}$

Amino Acid $\begin{aligned} & \text { Half-Wave } \\ & \text { Potential }\end{aligned} \stackrel{\sigma_{I}}{\text { Inductive const. }} \stackrel{\sigma}{*}^{*}$

N-Benzoyl-threo-B-

p-phenylcystine

ethyl

0.000

$+.49$

$\mathrm{N}$-Benzoy 1 -threo- $\beta-$

p-methoxyphenylcystine

ethyl ester

$-0.639$

$+.250$

$-.10$

N-Benzoy 1-threo- -

p-chlorophenyl-

cystine ethyl ester

$-0.638+.470$

$+.40$

N-Benzoy 1-threo- - -

p-nitrophenyl-

cystine ethyl ester

$-9.655$

$+.630$

$+.95$

$\underline{\sigma}_{I}$ Substituent constant (inductive)

o* Taft constant (polar substituent). 


\section{CHAPTER V \\ SUMMARY AND CONCLUSIONS}

A polarographic method was established for the determination of $\mathrm{N}$-benzoy $1-\underline{\beta}$-phenyl-, N-benzoyl- $\underline{\beta}-\underline{p}-$ methoxyphenyl-, N-benzoyl- $\underline{B}-\underline{p}-$ chlorophenyl-, and Nbenzoyl- $\underline{\beta}-\underline{p}-n i t r o p h e n y l c y s t i n e ~ e t h y l$ esters. All determinations were carried out in $0.1 \mathrm{M}$ sodium acetate in methanol at an apparent pH of 9.7. A straight-line correlation was established between the diffusion current and the concentration. The concentrations measured were between $1 \times 10^{-5}-1 \times 10^{-4} \mathrm{M}$. Slopes of the logarithmic analysis of $\left(i_{d}-i\right) / i^{2}$ versus $E$ gave values ranging from $0.0245-0.0185$. These values show that the reduction is nonreversible. Corrected values of half-wave potentials were determined from plots of voltage versus $\log \left(i_{d^{-i}}\right) / i$.

Absorption characteristics of these compounds ( $\mathrm{n}-\sigma^{*}$ transition) were measured in methanol and an attempt to establish a correlation between these values and half-wave potentials was attempted. Since there was a very little difference in half-wave potentials for these compounds, no correlation was found between halfwave potentials and the Taft's values (substituent constants). 
BIBLIOGRAPHY

1. Thibert, R.J., and Walton, R.J., Can. J. Chem., 45 713 (1967).

2. Carrol, J.E., Masters Thesis, University of Windsor, (1969).

3. Gould, E.S., Mechanism and Structure in Organic Chemistry, Holt, Rinehart and Winston, New York (1963).

4. Zuman, P., Substituent Effects in Organic Polarography, Plenum Press, New York. (1967).

5. Hall, M.E., Anal. Chem. 25, 556 (1953)

6. Karchmer, J.H., and Walker, M.T., Anal. Chem., 26, 271 (1954).

7. Taft, R.W., and Lewis, I.C., J. Am. Chem. Soc., 80, 2436 (1958).

8. Hammett, L.P., Physical Organic Chemistry, McGrawHill, New York, (1940) p. 184 .

9. Jaffe, H.H., Chem. Rev., 53, 191 (1953).

10. Brdicka, R., Collection Czech. Chem. Communs., 5, 238 (1933).

11. Roncato, A., Arch. Sci. Biol. (Italy), 20, 146 (1934).

12. Muller, O.H., Chem. Revs. , 24, 95 (1939).

13. Kolthoff, I.M., and Barnum, D., J. Am. Chem. Soc., 63 520 (1941).

14. Donahue, J.J., and Olver, J.W., Anal. Chem., 41, 753 (1969).

15. Jones, M.M., Nature, 185, 96 (1959).

16. Patt, H.M., Tyree, E.B., Stranbe, R.L., and Smith, D.E., Science, 110, 213 (1949).

17. Chapman, W.H., et al., Project NM 006012.08.25, Naval Medical Institute, $\bar{B}$ ethesda, Ma., Sept. (1949).

18. Thibert, R.J., and Sarwar, M., Mikrochim. Acta., 2, 259 (1969). 
19. Thibert, R.J., Sarwar, M. and Carrol, J.E., Mikrochim. Acta., 3, 615 (1969).

20. Bergman, I., Trans. Faraday Soc., 50, 829 (1954).

21. Silverstein, R.M., and Bassler, G.C., Spectrometric Identification of Organic Compounds, 2nd edition, John Wiley \& Sons, Inc., New York. (1967).

22. Cook, A.H., Harris, G., and Heilbron, I., J. Chem. Soc., 1060 (1948).

23. Svoboda, M., Sicher, J. and Farkas, J., Collection Czech. Chem. Communs. , 20, 1439 (1955).

24. Svoboda, M., Sicher, J., Farkas, J., Pankova, M., Chem. Listy, 49, 1351 (1935).

25. Erlenmeyer, E., Ann. Chem. 275 \&. 3 (1893).

26. Erlenmeyer, E., Stadin, W., Ann. Chem., 337, 265 (1904).

27. Erlenmeyer, E., et al, Ann. Chem., 337, 271 (1904).

28. Erlenmeyer, E., Ann. Chem., 307, 70 (1899).

29. Erlenmeyer, E., and Halsey, J.T., Ann. Chem., 307, 139 (1899).

30. Cremlyn, R.J.W., and Still, R.H., Named and Miscellaneous Reactions in Practical Organic Chemistry,

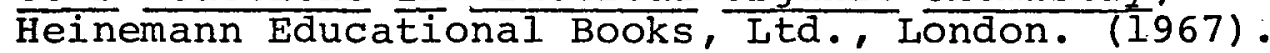

31. Brown, H.C., J. Am. Chem. Soc., 60, 1325 (1938).

32. Cunneen, J.I., J. Chem. Soc., 134 (1947)

33. Arthur, P., and Lyons, H., Anal. Chem., 24, 1422 (1952).

34. Lund, H. and Bjerrum, J., Chem. Ber., 64, 210 (1931B).

35. Kalousek, M., Grubner, O., and Tochstein, A., Chem. Listy, 47,1143 (1953).

36: Willard, H.H., Merritt, L.L., and Dean, J.A., Instrumental Methods of Analysis, D. Van Nostrand Co., (Canada), Ltd., Toronto, (1958).

37. Taylor, J.K., and Smith S.W., J. Res. Nat. Bur. Stand., 56, No. 3, $143(1956)$. 
38. Heilbron, I., J. Chem. Soc., 2099 (1949).

39. Cook, A.H. Heilbron, I., and Levy, A.L., J. Chem. Soc., 201 (1948).

40. Cook, A.H., Harris, G., Heilbron, I., Shaw, G., J. Chem. Soc. , 1050 (1948).

41. Cook, A.H., Harris, G., Pollock, J.R.A., and Swan, J. M. , J. Chem. Soc., 1947 (1950).

42. Cook, A.H., Harris, G., Heilbron, I., J. Chem. Soc., 1060 (1948).

43. Chatterjee, R., Cook, A.H., Heilbron, I., and Levy, A.L., J. Chem. Soc., 1337 (1948):

44. Heyrowsky, J., and Keta, J., Principles of Polarography, Academic Press, New York, (1966).

45. Kindler, K., Ann. Chem., 450, 1 (1926) .; 452, 90 $(1927) ; \underline{464}, 2 \overline{78}(1 \overline{928})$. 
VITA AUCTORIS

1933 Born in Bombay, India, on December 25, 1933.

1955 Graduated from University of Bombay with the degree of Bachelor of Science, in Chemistry.

1955-57 Attended Friedrich-Wilhelm-Universitat, Bonn, W. Germany.

1957-60 Attended Freien Universitat Berlin, Berlin, W. Germany.

1960-64 Worked in the Research Laboratories of the firm A.E.G. Fabriken Brunnenstrasse, Berlin, as a Chemist.

1965-66 Joined the pharmaceutical firm of "Empire Laboratories Limited", 301 Lansdowne Avenue, Toronto 3, Ontario.

1966 Employed by "Bel1-Craig Pharmaceuticals".

1966 Joined the staff of the Western Ontario Institute of Technology as an Instructor in Chemistry.

1967 Accepted into the Chemistry Graduate School of the University of Windsor. 